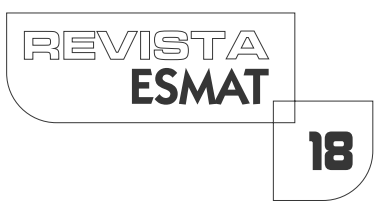

\title{
O DIREITO DAS RELAÇÕES PRIVADAS DOS MICROSSISTEMAS JURÍDICOS: UMA PERSPETIVA LUSO-BRASILEIRA (?)
}

LEGAL MICROSYSTEMS: A LUSO-BRAZILIAN PERSPECTIVE (?)

Daniel de Bettencourt Rodrigues Silva Morais

Doutor em Direito e Professor Auxiliar da Faculdade de Direito da Universidade de Lisboa.

\section{RESUMO}

A uma sociedade complexa corresponde uma ordem jurídica complexa. Sendo certo que o movimento recodificador foi questionado nos anos setenta, por Natalino Irti, num texto clássico relativo à "idade da descodificação", a verdade é que a proliferação de leis especiais aglomeradas em verdadeiros microssistemas ou Estatutos, que englobam normas de vários ramos de direito, constitui uma realidade que, ainda hoje, e após a confirmação da existência de um movimento de recodificação, se mantém no Brasil. A propósito da participação do autor num módulo de pós-graduação relativo ao "Direito das Relações Privadas dos Microssistemas Jurídicos", na Escola Superior de Magistratura Tocantinense, surgiu este texto, em que se afere a relevância dos microssistemas no direito brasileiro e se procuram reflexos dessa realidade no direito português. Encontram-se diferenças assinaláveis nesta matéria, que resultam da diferente "arquitetura" de ambas as ordens jurídicas.

PALAVRAS-CHAVE: Direito; Microssistemas jurídicos; Luso-brasileira.

\section{ABSTRACT}

A complex society demands a complex legal system. Although the recodification movement was questioned in the 1970s by Natalino Irti, in a classic book on the subject, the truth is that the proliferation of special laws agglomerated in true microsystems or Statutes, which include rules of various branches of law, is a reality that, even today, exists in Brazil, after the recodification movement has occurred. This text was written on the occasion of the author's participation in a postgraduate module on "Legal Microsystems", at the Superior School of Magistrature of Tocantins. The author analyses the relevance of the microsystems in Brazilian law and concludes that, in Portuguese law, this reality does not exist in the same way. The striking differences in this matter result from the different "architecture" of both legal systems.

KEYWORDS: Law; Legal microsystems; Luso-brazilian. 


\section{INTRODUÇÃO: MICROSSISTEMAS E UM CONVITE DA ESCOLA SUPE- RIOR DE MAGISTRATURA TOCANTINENSE}

Tive, recentemente, oportunidade de participar no curso de Pós-Graduação Lato Sensu em Direito Privado na Escola Superior de Magistratura Tocantinense. Foi um convite a que correspondi com gosto, mas maior foi o desafio, tendo em conta o tema a abordar: "O Direito das Relações Privadas dos Microssistemas Jurídicos". Como se trata de uma terminologia que não é utilizada na ordem jurídica portuguesa, a primeira questão que se me colocou foi a de identificar o conceito de microssistema e de aferir da existência de microssistemas no direito português. Trata-se do tema que me proponho abordar neste texto, analisando a questão no direito brasileiro e procurando aferir os seus reflexos no direito português. Saliente-se que os microssistemas são igualmente conhecidos por Estatutos ou até Minicódigos.

Antes de avançar para um enquadramento da questão no direito brasileiro, torna-se necessário olhar para a ordem jurídica italiana, em que surge a ideia de microssistema, em particular pela mão de Natalino Irti'.

\section{A “IDADE DA DESCODIFICAÇÃO” NA VISÃO DE NATALINO IRTI}

Para este autor, não podemos voltar "o mundo de ontem", visto que as potências do nosso tempo - políticas entenda-se, assim como foi política a ideologia subjacente aos códigos do século XIX - não se podem encerrar nos limites estáveis dos códigos ${ }^{2}$. Surge a "idade da descodificação" e da fragmentação da ordem jurídica em microssistemas, ficando o Código Civil relegado a uma função de "direito residual", disciplinando os casos não contemplados pelas normas particulares. "Não é tanto verdade que as leis especiais desenvolvem os critérios enunciados no Código, quanto que o Código integra e completa as previsões das leis especiais"”. Entre as duas grandes guerras, "ao reino da imutabilidade e do duradouro sucede a nervosa «aceleração histórica». Perante a multiplicação de leis especiais, os códigos assumem uma função diferente, deixando de representar o direito exclusivo e unitário das relações privadas e constituindo, pelo contrário, um direito comum, ou seja, a disciplina de situações mais amplas e gerais ${ }^{4}$. Nesse período, que se pode

Cfr. Natalino irti, «L'Etádelladecodificazione» Vent'anni dopo, Milano, Guiffrè, 1998. Todas as citações textuais desta obra correspondem a traduções realizadas por mim.

2 Cfr. Natalino Irti, op. cit., p. 12.

3 Natalino Irti, op. cit., p. 40.

4 Irti aponta a falência das tentativas de penetrar no velho edifício do Código Civil, dando como exemplo a experiência italiana da reforma do Direito da Família, em 1975, visto que foi introduzida no Código Civil de 1942 uma lógica diversa, com um novo léxico jurídico, que suscitou antinomias interpretativas. Assim, estas novidades, ou criam conflitos insanáveis entre 
dizer de transição, surge o Código Civil italiano, de 1942, que manteve substancialmente a tradição ${ }^{5}$.

O surgimento da Constituição Republicana, em $1^{\circ}$ de janeiro de 1948, constituiu uma alteração de fundo na ordem jurídica italiana, que não pôde deixar de ter consequências no próprio Código Civil. Apesar de manter a tradição oitocentista no que se refere às liberdades políticas e cívicas, pela influência católica e socialista, novas figuras são acrescentadas ao elenco tradicional dos direitos, numa ótica de maior valorização do homem e das relações económicas e sociais. $O$ cidadão já não é visto somente como indivíduo, mas, igualmente, como membro de grupos intermédios. Este novo pano de fundo do ordenamento jurídico italiano implicou uma aceleração do ritmo de produção de normas especiais para atender a ests nova qualidade do indivíduo. A Constituição assume uma influência no conteúdo e forma da legislação ordinária ${ }^{6}$.

Tendo isso em conta, é particularmente no campo das leis especiais que se vai sentir a influência constitucional, cuja ideologia contrasta com o patrimonialismo ainda subjacente ao Código Civil, de 19427. Tais leis regulam matérias e relações anteriormente previstas no Código Civil, que vai sendo esvaziado de conteúdo. A legislação dita especial consolida-se e exprime princípios que adquirem um alcance geral, não se limitando a constituir um mero desenvolvimento da disciplina geral prevista no Código. Surgem "lógicas autónomas e princípios orgânicos, que, primeiro, se contrapõem àqueles que são fixados no Código Civil, e acabam por suplantá-los totalmente". A uma fase de conflito sucede-se um momento de prevalência e substituição. Nesse novo contexto, torna-se necessário repensar o problema da interpretação sistemática e da analogia juris, em particular, considerando que, afastado o Código Civil do centro do direito privado, as leis especiais passaram a constituir "o direito geral de um instituto ou de uma matéria na sua totalidade" configurando verdadeiros

princípios, ou perdem a singularidade da sua lógica nas antigas estruturas do Código (op. cit., p. 48). Pelo contrário, Irti aponta como exemplo de um microssistema autónomo e separado as leis especiais em matéria de arrendamento (op. cit., p. 105 e ss).

5 Natalino Irti, op. cit., pp. 26-29.

6 Natalino Irti, op. cit., pp. 29-30 e 68.

7 "O Código Civil, já com seis anos, pertence ao passado: a legislação especial constitui um instrumento necessário e inerradicável que implementa os princípios da Constituição para institutos individuais ou para categorias de interesses. A especialidade assume um novo significado: não mais o desenvolvimento dos critérios já acolhidos no Código Civil, ou introduzidos pelo legislador ordinário, mas realização de princípios constitucionais. Não mais uma relação de género e espécie, mas de programa em execução. Agora, as normas especiais caraterizam-se como normas implementadoras de princípios constitucionais. Na hierarquia das fontes, normas do Código Civil e normas especiais, enquanto normas ordinárias, ocupam o mesmo grau; no aspeto histórico-político, umas encontram-se aquém e outras além da entrada em vigor da Constituição. Se a sequência diacrónica é Código Civil - Constituição - normas especiais somente estas últimas podem implementar os princípios da Carta republicana" (Natalino Irti, op. cit., p. 75). 
"estatutos de grupos". Nesse cenário, a tutela do status, ou seja, a posição do indivíduo nas diversas comunidades sociais, realiza-se mediante aquilo que é negociado com as autoridades públicas. O indivíduo já não se encontra, portanto, "só e despido" perante os poderes públicos, mas refugia-se no interior do grupo, dependendo a sua proteção da capacidade de pressão e de ameaça que tal grupo constitui para os referidos poderes ${ }^{8}$. $\bigcirc$ princípio da igualdade não impele para a uniformização, mas para a diferenciação, tendo-se em conta as qualidades dos sujeitos e as suas singularidades económicas. Esmagados que são os institutos jurídicos, as figuras tradicionais decompõem-se. Assim, já não existe uma propriedade, mas diversas propriedades; já não há uma locação, mas diversas locações; a venda multiplica-se em vendas etc. .

Nesse novo período, o Código Civil deixa de ter qualquer "valor constitucional" e, fora da legitimidade da própria Constituição, não existe outra forma de estabelecer a unidade do tratamento jurídico e de tutelar a igualdade concreta entre os cidadãos do que um sistema rigoroso de relações de poder entre o Estado e o poder dos grupos. Por isso, e de modo mais amplo, pode-se dizer que o problema do Código Civil é um problema de poder; sendo a crise da "centralidade" do Código Civil um reflexo da crise do Estado moderno e do surgimento de grupos e de categoriais económicas de elites que exigem estatutos legais específicos ${ }^{10}{ }^{\prime \prime}$. Consequentemente, as leis que surgem com uma natureza excecional e provisória adquirem uma estabilidade inesperada. Em seu redor surgem outras leis que completam a sua disciplina, surgindo, desse modo, um microssistema, ou seja, "um pequeno mundo de normas" de que o intérprete pode retirar princípios gerais e em que pode descobrir uma lógica autónoma. Nesse contexto, como já referido, o Código Civil deixa de assumir uma função de direito geral e passa a constituir uma disciplina residual. Para Irti, o nosso tempo não é o de novas codificações ou de reformas gerais. Restarão ao Código Civil somente os velhos institutos, como a sucessão testamentária ou certos aspetos do Direito das Obrigações ou dos Direitos Reais ${ }^{12}$.

No processo que se vem descrevendo, as normas especiais não correspondem a um reino do arbítrio, mas ao surgimento de novas "lógicas de setor". Estas consolidam-se em conjuntos de normas especiais, que, dirigindo-se a institutos jurídicos particulares ou a certas classes de relações, têm princípios em comum. Não se trata de subsistemas, visto que estes implicam uma lógica de subordinação. Pelo contrário, estamos perante intersistemas, ou seja, relações entre sistemas de normas definidas com base no seu conteúdo. A unidade do sistema jurídico vai-se perdendo com

8 Natalino Irti, op. cit., pp. 39-4I.

9 Natalino Irti, op. cit., p. 95.

10 Veja-se que a palavra privilégio vem, precisamente, de privuslex, ou seja, lei privada.

1 Natalino Irti, op. cit., pp. 42, 44 e 49.

12 Natalino Irti, op. cit., pp. 46-48. 
essa fragmentação ${ }^{3}$. $\bigcirc$ Código Civil passa a ser um sistema entre outros sistemas e a ordem jurídica evolui de um monossistema para um polissistema, cuja unidade é garantida pela Constituição ${ }^{14}$. Esta, introduziu no sistema um elemento de certeza e estabilidade. "A certeza de ontem fundava-se naquilo que a norma dizia; a certeza de hoje, naquilo que a norma ordinária não pode dizer (devido ao controlo de legitimidade constitucional)"15.

Nessa nova face da ordem jurídica, o papel do jurista também muda: ele é chamado à tarefa da exegese e de construção dos microssistemas. A estabilidade do Código Civil permitiu considerar encerrada a idade da exegese, relevando, fundamentalmente, a construção sistemática; pelo contrário, as normas especiais implicam tarefa quotidiana de leitura técnica. $\bigcirc$ jurista surge como um "técnico dos microssistemas: exegeta e organizador de um conjunto de normas especiais". A construção dos microssistemas deve partir do Código Civil, visto que este continua a ser o mais "rico e refinado arsenal de instrumentos jurídicos"|6. Este retorno à exegese constitui "a mais série e conspícua consequência da crise da unidade". Num rigoroso experimentalismo, o jurista exercita a exegese das leis, tentando, depois, estabelecer conexões lógicas entre as normas e grupos e normas; isso tendo consciência da implacável mudança das normas e da relatividade histórica dos conceitos jurídicos ${ }^{17}$.

Num polissistema adquire particular relevância o problema de saber como resolver a sucessão de uma geral a uma norma especial: se, por um lado, de acordo com o critério cronológico (lex posterior derogat priori), a norma geral posterior deveria prevalecer sobre a norma especial anterior; segundo o critério da especialidade (lex posterior generalis non derogat priori speciali), a norma especial anterior deveria conservar a sua eficácia ${ }^{18}$. Tendo em conta que a qualificação de uma norma como especial traduz um atributo relacional, a mudança de uma das normas em confronto implicará uma mudança das outras normas dessa relação. Nesse sentido, a norma geral sucessiva somente pode ser qualificada como tal relativamente à norma especial anterior e vice-versa. Por isso, uma norma especial anterior que disponha num sentido contrário à norma geral posterior, assumirá, logicamente, a qualificação de norma excecional. Se a norma geral posterior indicar um número fechado de exceções, então a norma especial anterior (convertida em norma excecional), será revogada.

13 Natalino Irti, op. cit., pp. 70-72.

14 Natalino Irti, op. cit., p. 76.

15 Natalino Irti, op. cit, p. 96.

${ }^{16}$ Natalino Irti, op. cit., pp. 98-99.

17 Natalino Irti, op. cit., p. 182.

18 Trata-se de uma questão que assumiu particular importância no direito brasileiro no que se refere à relação entre o CCB de 2002 e o Código de Defesa do Consumidor, que the é anterior. 
De qualquer forma, salvo esta última situação, a sucessão de uma norma geral a uma norma especial anterior será resolvida com base no critério da especialidade: a lei especial, ainda que anterior, derroga a lei geral, mesmo que posterior ${ }^{19}$.

Igualmente relevante no polissistema é a forma como são resolvidos os conflitos entre princípios gerais. Assim, por exemplo, enquanto o Código Civil estabelece o princípio da liberdade na determinação dos preços, as leis especiais consagram o princípio da determinação heterónoma destes, por meio de uma autoridade administrativa. A doutrina tradicional resolve o conflito pela técnica da exceção, negando à norma exterior ao Código a capacidade de exprimir um princípio geral, o que se traduz não na resolução do problema, mas na sua negação. A conceção polissistémica vê o referido conflito como sinal de um movimento fecundo e de uma crise criativa, sendo a questão ultrapassada com base em critérios diversos: desde a identidade ou diversidade das matérias reguladas, ao recurso às normas superiores de caráter

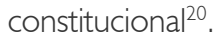

Para Mário Luiz Delgado²', a tese de Natalino Irti é compreensível tendo em conta a época em que concebida, ou seja, 1978. Nesse momento, a dispersão das fontes permitia e sustentava essa visão e nem sequer estava ainda no horizonte a força da recodificação, nomeadamente, tendo em conta a reforma do $B G B$, de 2001 2002. O movimento foi, precisamente, no sentido contrário ao preconizado por Irti: - Código Civil absorveu matérias anteriormente tratadas em leis especiais v.g. como ocorreu com a matéria de Direito do Consumidor, absorvida pelo BGB. E mesmo que tal absorção não ocorra, o Código estabelece princípios ou cláusulas gerais que permitem a integração e a interação do sistema. $\bigcirc$ mesmo se deu com o Código

19 Natalino Irti, op. cit., pp. 79-8I.

20 Natalino Irti, op. cit., pp. 184-185. Trata-se de uma questão que aponta no sentido do diálogo das fontes tal como preconizado no Brasil por Cláudia Lima Marques, na sequência das ideias defendidas por Erik Jayme (cfr. o ponto n. 5 deste estudo).

21 Mário Luiz Delgado, Codificação, descodificação e recodificação no direito civil brasileiro, São Paulo, Editora Saraiva, 20 I I, pp. 247-248. Também Paulo Lôbo salienta que as teses de Natalino Irti foram, em certa medida, negadas pela própria realidade da recodificação [cfr. "Novas perspectivas da constitucionalização do direito civil", disponível em: https://jus.com.br/ artigos/2536 I/novas-perspectivas-da-constitucionalizacao-do-direito-civil (consultado a 8-0720 I9),em particular, cfr. o ponto n. 3 ("Críticas à constitucionalização do direito civil"]. Cfr., igualmente, António Menezes Cordeiro, ao salientar que, apesar de ter sido proclamada a idade da descodificação "a Ciência do Direito continental retomou, todavia e com alguma facilidade, o seu ascendentes sobre o Direito e a produção de leis", o que afastou "um pensamento de tipo cético e pessimista, que punha em dúvida a valia do pensamento abstrato e sistemático, de saber transcendental, ancorado na dupla Kant/Hegel", [cfr. Tratado de Direito Civil, I - Introdução, fontes do direito, interpretação da lei, aplicação das leis no tempo, doutrina geral, 4. ${ }^{a}$ edição (reformulada e atualizada), Coimbra, Almedina, 20।2,p. I49]. 
Civil brasileiro22, de 2002, que voltou a regular matérias que se encontravam anteriormente reguladas em legislação especial (v.g. união estável, alienação fiduciária, sociedades limitadas etc.) e que introduziu, igualmente, cláusulas de integração sistemática em diversas matérias (v.g. responsabilidade civil objetiva, Direito do Consumidor, direitos da personalidade, Direito Societário etc.). Este Código também revogou tacitamente diversas leis especiais.

Na minha opinião, a tese de Natalino Irti não deixa de ser um contributo fundamental para a compreensão da complexidade das diversas ordens jurídicas na atualidade. A tese "assenta que nem uma luva" à ordem jurídica brasileira. Embora, como referirei no ponto seguinte, se possa apontar a existência de um movimento recodificador, esta tese teve o mérito de salientar que as "regras do jogo" mudaram de forma irreversível, tendo-se operado uma revolução coperniciana no centro da ordem jurídica. E se a tese dele foi contrariada, até certo ponto, pela realidade, no que se refere ao futuro da ordem jurídica - segundo Irti, a codificação constituiria um fenómeno ultrapassado -, não deixa de ter sido confirmada noutro tanto, quando se atende à importância do processo de diferenciação existente na ordem jurídica atual, traduzido em leis especiais que se foram consolidando, e que constituem verdadeiros microssistemas, ao lado do macrossistema que o Código Civil representa. Parece-me, em suma, que, se um certo movimento recodificador é inegável, inegável é, igualmente, a existência de microssistemas jurídicos.

No Brasil, a realidade dos microssistemas é bastante clara, constituindo um campo rico de análise. É, no entanto, de salientar a diferença entre o "valor político" do Codice Civile, de 1942 - "que é uma lei identificada com a realidade cultural italiana, que se manteve íntegra e adaptada, apesar das constantes crises constitucionais e políticas na Itália -, e o reduzido "valor político" do Código Civil Brasileiro (CCB), de 2002 - "projetado durante a ditadura militar brasileira, frente à força normativa da democrática Constituição Federal brasileira"23. Tendo em conta esta ressalva, Cláudia Lima Marques ${ }^{24}$ entende que a lição de Natalino Irti pode servir de inspiração; em particular as ideias de "centralidade, subsidiariedade e pluralidade". A análise do problema dos microssistemas jurídicos no direito brasileiro convoca diversas questões:

22 De agora em diante mencionado como CCB.

23 As palavras são de Cláudia Lima Marques, "Superação das antinomias pelo diálogo das fontes: o modelo brasileiro de coexistência entre o Código de Defesa do Consumidor e o Código Civil de 2002", Revista da Escola Superior de Magistratura de Sergipe, n. ${ }^{\circ}$ 7, 2004, pp. I 5-54, em particular, p. 18. Também Menezes Cordeiro salienta que, enquanto alguns autores brasileiros aplaudem o CCB, outros consideram-no "prematuramente envelhecido" (cfr. Tratado de Direito Civil, I - Introdução, fontes do direito, interpretação da lei, aplicação das leis no tempo, doutrina geral, p. 154).

${ }^{24}$ Cláudia Lima Marques, ibid. 
a) Qual a forma de articulação entre os microssistemas e o Código Civil Brasileiro?

b) Qual a importância do Código Civil no direito brasileiro?

c) Qual o papel da Constituição Federal no direito privado brasileiro?

d) Que orientações devem os julgadores brasileiros seguir para lidar com a complexidade do direito brasileiro?

Eis o fio condutor que me vai orientar numa análise da matéria no direito brasileiro. Fica, no entanto, a constatação de que o estudo que fiz das ideias de Natalino Irti terá, já, fornecido algumas pistas para a resolução das questões em causa.

\section{A CRISE CÍCLICA DAS CODIFICAÇÕES E OS MICROSSISTEMAS NO DI- REITO BRASILEIRO 25}

A evolução do Direito é sempre marcada por movimentos cíclicos e alternados de concentração e de fragmentação das fontes. Utilizando a terminologia hegeliana, uma tese implica uma antítese, para, no final, termos a síntese. Este movimento é comprovado pela História, se tivermos em conta o processo de codificação oitocentista, a que se seguiu o declínio da codificação no século $X X$; verificando-se, finalmente, na última década do século $X X$ e no início do século $X X \mid$, um novo fôlego da codificação com o Código Civil do Quebeque (|99|), o Código Civil holandês ( | 992), com a reforma do BGB (200 I), e com a discussão em torno da elaboração de um Código Civil Europeu².

Tal como ocorre a qualquer ser humano, também faz parte da natureza de um Código que, assim que entra em vigor, começa a envelhecer, para um dia vir a morrer. É a inevitável evolução da sociedade que o dita, tendo em conta que o Direito existe para ser aplicado, e não para ficar encerrado nos livros. $\bigcirc$ surgimento de novas questões implica a necessidade de diplomas situados fora dos Códigos. A partir de certo momento, a sistematização que o Código implica começa a ser posta em causa devido ao excesso de dispersão dos textos legais, e tudo isso gera insegurança jurídica. Em particular, na sociedade contemporânea, marcada por uma dinâmica e pluralidade nas suas relações, este movimento acentua-se. Atingindo o processo um certo ponto, procura-se novamente a ordem, surgindo um movimento de recodificação. Claro está, como referi no ponto anterior, que, nesse processo, o surgimento de microssistemas não será apagado - ou, pelo menos, totalmente apagado - por

25 Sobre este ponto, cfr. Mário Luiz Delgado, op. cit., pp. 221-237.

26 Trata-se de uma discussão que foi objeto da minha dissertação de mestrado, especificamente centrada na unificação do Direito Sucessório (cfr. Daniel Morais, Viabilidade de uma unificação jus-sucessória a nível europeu: unificação meramente conflitual ou unificação material?, Coimbra, Almedina, 2005). 
essa eventual recodificação. Também se pode dar o surgimento de consolidações ou seja, a alteração dos textos existentes e união em um só texto - como ocorreu no Chile ou em França.

Nesse movimento, o primeiro passo, conforme referi, é o processo de envelhecimento dos códigos. Tal como ocorre em relação às pessoas, o envelhecimento dos códigos também não se dá de modo uniforme, tudo depende da permeabilidade que estes têm às mudanças sociais. Por vezes, o próprio legislador opta por consagrar "zonas abertas", autênticas lacunas talvez, para permitir que os Códigos se adaptem à sociedade. Nesse âmbito, podemos apontar a importância das cláusulas gerais e dos conceitos indeterminados ${ }^{27}$. A esse propósito, diz-nos o grande Mestre Baptista Machado que: "a ordem jurídica precisa de assentar em conceitos claros e num arcaboiço de quadros sistemáticos conclusivos para que seja garantida a segurança ou certeza jurídica. Mas também, por outro lado, e sobretudo nos tempos actuais, precisa de se abrir à mudança das concepções sociais e às alterações da vida trazidas pela sociedade técnica - isto é, precisa de adaptar-se e de se fazer permeável aos seus próprios fundamentos ético-sociais". Assim, surgem os conceitos indeterminados e cláusulas gerais que "constituem por assim dizer a parte movediça e absorvente do mesmo ordenamento, enquanto servem para ajustar e fazer evoluir a lei no sentido de a levar ao encontro das mudanças e das particularidades das situações da vida"28.

Assim, por exemplo, apesar de não existir divórcio a pedido em Portugal, na leitura da maioria da doutrina, determina o artigo $1.781^{\circ}$, d), do Código Civil português ${ }^{29}$, como fundamento de divórcio sem consentimento de um dos cônjuges: "quaisquer outros factos que, independentemente da culpa dos cônjuges, mostrem a ruptura definitiva do casamento". Trata-se de uma cláusula geral. Por outro lado, resulta do o artigo 1.906\% CCP que: "As responsabilidades parentais relativas às questões de particularimportância para a vida do filho são exercidas em comum por ambos os progenitores nos termos que vigoravam na constância do matrimónio, salvo nos casos de urgência manifesta, em que qualquer dos progenitores pode agir sozinho, devendo prestar informações ao outro logo que possível". Estamos, claramente, perante a utilização de conceitos indeterminados. Verifica-se, aliás, que uma

27 Aspeto salientado por Gustavo Tepedino, "O Código civil, os chamados microssistemase a Constituição: premissas para uma reforma legislativa", in Gustavo Tepedino (Org.), Problemas de direito civil-constitucional, Rio Janeiro, Renovar, 2000, pp. I-16, em particular, pp. I0- I I, disponível em: http://www.tepedino.adv.br/wpp/wp-content/uploads/20 17/07/Codigo_civil_chamados_microssistemas_constituicao_fls_000 I-00 I 6.pdf (consultado a 4-7-20 I 9).

${ }^{28}$ Para ambas as citações, cfr. João Baptista Machado, Introdução ao Direito e ao Discurso Legitimador, Coimbra, Almedina, 2000, p. 113.

29 De agora em diante mencionado como CCP. 
das caraterísticas do Direito da Família português do século $X X \mid$ é, precisamente, a utilização de conceitos indeterminados ${ }^{30}$.

Como exemplos de Códigos que souberam envelhecer porque têm essas caraterísticas, temos o BGB e o Código Civil suíço. Também o Código Civil brasileiro tem estas caraterísticas, que Ihe permitirão envelhecer. Na concretização das cláusulas gerais e dos conceitos indeterminados, o juiz deve atender aos princípios constitucionais e infraconstitucionais.

Na vigência do Código Civil brasileiro, de 1916, o código era o "centro de gravidade" do direito privado: um verdadeiro monossistema, que levava ao extremo o dogma da plenitude do ordenamento jurídico. Como vimos, a evolução da sociedade alterou essa situação, passando o Código a constituir apenas mais um dos elementos de um ordenamento jurídico complexo, ou seja, mais um sistema no contexto de um polissistema, fragmentado por uma pluralidade de estatutos autónomos, diretamente conectados com a Constituição Federal. A esta cabe um papel central na reunificação do sistema em termos interpretativos, pista já deixada nas teses de $\mid r t^{3 !}$.

Nas palavras do doutrinador brasileiro Francisco Amaral32: "se a codificação é uma síntese histórica, a descodificação representa uma antítese. Se a codificação resulta do racionalismo europeu, a época atual, iniciada com a maré da legislação especial e extravagante, a partir das primeiras décadas do século, representa o movimento e a pluralidade no direito, comprovando a crise da unidade sistemática do direito civil, senão a própria recusa à ideia de sistema. $\bigcirc$ Código Civil não mais garante a unidade do direito privado, deixando a posição central que nele ocupava e passando o centro do poder civil à própria Constituição, agora o eixo em torno do qual gravita todo o ordenamento jurídico da sociedade brasileira. Não mais o regime do monossistema, sob a égide do Código Civil unitário da época liberal, que exprimia uma visão compreensiva da sociedade, mas o polissistema, como pluralidade de núcleos jurídicos que representam a fragmentação dessa unidade, cada um com seus próprios princípios e lógicas interpretativas. $\bigcirc$ Estado, de espectador que era na época moderna, faz-se protagonista, e o civilista, que antes se configurava como o estudioso enciclopédico do direito privado, surge agora como especialista sectorial, como técnico de microssistemas ou de leis especiais, como personagem secundário". Palavras em que se vê o eco claro das ideias de Irti!

30 Nesse sentido, cfr. Jorge Duarte Pinheiro, O Direito da Família Contemporâneo, 6. ${ }^{a}$ edição, Lisboa, Associação Académica da Faculdade de Direito de Lisboa, 20। 8, p. 56.

31 Cfr. Gustavo Tepedino, op. cit., pp. 5 e 13.

32 Francisco Amaral, "Transformação dos sistemas positivos: a descodificação do direito civil brasileiro", disponível em: http://www.anoreg.org.br/index.php?option=com_content\&view $=$ article\&id =398:imported_366\&catid=32\&ltemid = |8| (consultado a 15-07-20 I8), ponto n. ${ }^{\circ} 8$ ("Conclusões. A insuficiência de razões que justifiquem um novo Código Civil"). 
Em diversas áreas o Código Civil brasileiro, de 1916, se mostrou desadequado, como no que se refere:

a) à proteção do ambiente, que sofreu danos com o progresso na área industrial, não se mostrando o Direito das Coisas, nem o regime da responsabilidade civil, aptos a dar respostas adequadas às necessidades ambientais concretas, com interesses difusos, danos coletivos e agentes anónimos;

b) às relações de consumo, em que a liberdade contratual do economicamente mais forte punha em causa qualquer paridade;

c) às relações de trabalho, antes subsumidas à disciplina da prestação de serviços;

d) às novas relações contratuais típicas, que exigiram uma regulamentação própria que não se enquadrou na moldura do velho código (v.g. contratos bancários, franchising etc. $)^{33}$.

E precisamente tendo em conta essa inadequação, começam a proliferar diversos microssistemas jurídicos, sob a forma de Estatutos autónomos: v.g. Direito Agrário, Direito do Trabalho, Direito Previdenciário, Direito Societário, Direito Bancário, Direito Notarial, Direito Concorrencial e, mais recentemente, Direito do Consumidor e Direito Ambiental.

Como aponta Mário Delgado ${ }^{34}$, estes Estatutos regulam sectores inteiros da sociedade e abrangem normas de Direito Civil, mas também de Direito Administrativo, Processual e Penal, sendo dotados de princípios e métodos de interpretação próprios. Ou seja, como vimos, são leis esparsas que atendem a particularismos jurídicos, exprimindo a vontade de grupos e corporações, sendo que a proteção destes grupos e corporações no polissistema depende diretamente da sua dimensão e grau de organização. Representam, em suma, compromissos conjunturais entre interesses particulares. Parece-me feliz a definição dos microssistemas como "um conjunto organizado de normas, princípios e regras tendentes a expressar lógica e unidade às relações jurídicas de determinados grupos, minorias ou temas, abarcando normas de direito material e processual, público e privado"35. Ou seja, autênticas ilhas legislativas dotadas de lógica jurídica própria. Os microssistemas distinguem-se dos Códigos "cujos traços residem num grau mais amplo de abrangência temática, porém limitado a um ramo da ciência jurídica"36. Anuncia-se, por isso, verdadeiramente, a "era dos Estatutos" ${ }^{37}$.

33 Cfr. Mário Delgado, op. cit., pp. 230-231.

34 Mário Delgado, op. cit., pp. 23 I-232.

35 Cfr. Fernando António Sacchetim Cervo, "Codificação, descodificação e recodificação do monosistema ao polissistema jurídico", Revista Magister de Direito Civil e Processual Civil, 58, 2014, pp. 80-86, em particular, p. 83.Disponível em: http://www.lex.com.br/doutrina_26099622_CODIFICACAO_DESCODIFICACAO_E_RECODIFICACAO_DO_MONŌSSISTEMA_AO_POLISSISTEMA_AJRIDICO.aspx (consultado a 04-07-2019).

${ }^{36}$ Fernando António Sacchetim Cervo, op. cit., p. 81.

${ }^{37}$ Nas palavras de Gustavo Tepedino, "A evolução do cenário económico e social passou a exigir do legislador uma intervenção que não se limita à tipificação de novas figuras de direito 
Os microssistemas apresentam as seguintes vantagens:

Conferem tratamento sistemático a institutos até então disseminados pela ordem jurídica;

Geram segurança jurídica por trazerem conceitos e regras específicas ou setoriais;

Regulam exaustivamente as matérias, abrangendo diversos ramos de direito;

Respondem de forma adequada à complexidade crescente das relações sociais;

Permitem uma modificação mais célere do seu conteúdo se comparadas com os códigos;

Concretizam a personalização das normas jurídicas, que passam a considerar aspetos particulares das relações jurídicas ${ }^{38}$.

Como aponta Mário Delgado ${ }^{39}$, no Direito brasileiro, a tendência para a descodificação começa a ganhar terreno a partir da Constituição, de 1934, com o Código de Minas, Código de Águas, Código de Menores, Código Florestal, e a própria Consolidação das Leis do Trabalho. Entre 1824 e 1930, o Brasil tinha apenas os Códigos Civil e Penal e os respectivos Códigos de Processo, além do Código Comercial, de 1850. Após a Constituição Federal, de 1988, destaca-se na legislação esparsa o chamado Código de Defesa do Consumidor ${ }^{40}$ (Lei n 8.078, de 1990), que retirou ao Código Civil brasileiro toda a matéria obrigacional que envolvesse a relação jurídica de consumo. No contexto de uma reunificação do sistema em termos interpretativos, "a vigência do Código do Consumidor (...) tem sido fecunda: os princípios da boa-fé objetiva e do equilíbrio das prestações reduzem a importância da vontade individual, em obediência aos princípios constitucionais da dignidade da pessoa humana, da solidariedade social e da igualdade substancial, que integram o conteúdo do Estado social de direito delineado pelo constituinte"4l. Ao lado do Código de Defesa do Consumidor existe uma gama de normas que, juntas, compõem o microssistema de proteção ao consumidor ${ }^{42}$. A este propósito, é importante salientar que este Código não constitui um verdadeiro Código, nomeadamente, tendo em conta a sua natureza multidisciplinar.

privado (antes consideradas de direito especial), abrangendo, ao revés, uma legislação própria, toda uma vasta gama de relações jurídicas que atingem diversos ramos de direito. Cuida-se de leis que regulamentem exaustivamente extensas matérias, e passam a ser designadas como estatutos, veiculando não apenas normas de direito material, mas também processuais, de direito administrativo, regras interpretativas, e mesmo de direito penal. Anuncia-se, em doutrina, a era dos estatutos". O itálico é meu (cfr. op. cit., p. 4).

38 Sobre estas vantagens, cfr. Fernando Cervo, ibid.

39 Mário Delgado, op. cit., p. 232.

40 De agora em diante designado Código de Defesa do Consumidor.

41 Nas palavras de Gustavo Tepedino, op. cit., p. 13.

42 Cfr. Mário Delgado, op. cit., p. 235. 
Ainda como exemplos de microssistemas, podemos apontar:

a) $\bigcirc$ Estatuto da Criança e do Adolescente (Lei n. ${ }^{0}$ 8.069, de 1990), que tem uma particularidade no plano dos princípios, qual seja, o melhor interesse da criança, e institutos específicos, como as medidas socioeducativas, previstas no artigo II $2^{\circ}$; a liberdade assistida, do artigo I I8; a semiliberdade, do artigo $120^{\circ}$ etc.;

b) $\bigcirc$ Estatuto do Idoso (Lei no 10.74I, de 2003), que traz alguns institutos próprios, como o transporte interurbano gratuito, caso haja o preenchimento de condições muito especiais presentes no artigo $39^{\circ}$ e ss., assim como a acessibilidade ao lazer com requisitos específicos para o seu exercício;

c) $\bigcirc$ Estatuto da Igualdade Racial (Lei n 12.288, de 2010);

d) $\bigcirc$ Estatuto da Juventude (Lei no 12.852, de 2013) etc.

Essa multiplicação de textos esparsos constituiu uma das caraterísticas dominantes da legislação anterior à entrada em vigor do Código Civil brasileiro, de 2002, gerando numerosas antinomias com o direito codificado. Como afirma, de forma tão enfática, Mário Delgado ${ }^{43}$, lentamente, os antigos civilistas transformam-se em especialistas: surgem os familiaristas, os contratualistas, os consumeristas, os menoristas, os agraristas, os ambientalistas, os peritos em direitos autorais, em direito imobiliário, em direito bancário, em direito societário etc. Para o mesmo autor, essa realidade alcançou o seu auge entre 1988 e 2002 e somente será ultrapassada, como já vai ocorrendo, pelo diálogo entre os microssistemas e o Código Civil brasileiro, tendo como pano de fundo a Constituição Federal.

\section{A IMPORTÂNCIA E OS REFLEXOS DA CONSTITUCIONALIZAÇÃO DO DIREITO PRIVADO BRASILEIRO}

A constitucionalização do direito civil teve também um papel relevante no direito brasileiro, dando o "golpe de misericórdia" no Código Civil brasileiro, de 1916. Constitui uma realidade que demonstra que o direito civil brasileiro hodierno integra um "sistema híper-complexo", que tem a Constituição Federal no seu vértice ${ }^{44}$.

Não deixa de ser curioso verificar que, mesmo o Código Civil brasileiro, de 2002, consagra uma abordagem patrimonialista, também ela contrastante com a matriz pessoal da Constituiçãa Federal (dignidade da pessoa humana). Esta, de todo o modo, constitui a "lente" pela qual toda a leitura da ordem jurídica brasileira é

\footnotetext{
43 Mário Delgado, op. cit., pp. 236-237.

44 Utilizando uma expressão feliz de Paulo Lôbo, op. cit., ponto n. ${ }^{\circ} 8$ ("Imprescindibilidade da constitucionalização do direito civil").
} 
realizada ${ }^{45}$. Logo, desde a Constituição brasileira, de 1934, verifica-se uma mudança fundamental, pois esta deixa de se reportar somente à organização do Estado e da tutela do indivíduo contra o poder político, passando a abordar temas que antes se encontravam somente no Código Civil, tais como aqueles que se referem à propriedade, aos contratos e à família. Tal como descrito por Natalino Irti, o mesmo processo verificou-se em Itália, com a Constituição, de 1948, cujo caráter democrático gerou dificuldades de articulação com um Código Civil ainda do tempo do fascismo. No Brasil, trata-se de uma situação que atinge o seu ponto máximo com a Constituição Federal, de 1988, dando impulso a uma nova corrente doutrinária a que se convencionou chamar Direito Civil Constitucional46_47.

processo de constitucionalização do direito privado não se espelha unicamente no tratamento constitucional de certas matérias tradicionalmente reservadas à órbita civil, mas, igualmente, na ideia de uma aplicação direta dos princípios constitucionais e dos direitos fundamentais positivados na Carta Magna à horizontalidade das relações privadas ${ }^{48}$. Para alguns doutrinadores, esse processo marca $\circ$ fim da oposição entre direito público e direito privado, visto que o Direito visa a um objetivo único: disciplinar a colaboração humana, de modo que a todos possam ser asseguradas vida e existência dignas ${ }^{49}$. $\bigcirc$ reflexo das "lentes da Constituição" em toda a ordem jurídica brasileira implica, também, uma "repersonalização" de todo o direito civil, numa nova

45 Mário Delgado utiliza, precisamente, a expressão “lentes da Constituição" (op. cit., p. 243).

46 Cfr. Mário Delgado, op. cit., pp. 237-239.

47 Segundo Mário Delgado (op. cit., p. 239), no Brasil, esta corrente foi capitaneada por: Gustavo Tepedino, no Rio de Janeiro; Luiz Edson Fachin, no Paraná; Paulo Luiz NettoLôbo, no Recife; João Baptista Villela, em Mina Gerais; Junqueira de Azevedo e Renan Lotufo, em São Paulo. Segundo Paulo Lôbo "A constitucionalização do direito civil, no Brasil, é um fenómeno doutrinário que tomou corpo, principalmente a partir da última década do século $X X$, entre os juristas preocupados com a revitalização do direito civil e sua adequação aos valores que tinham sido consagrados na Constituição de 1988, como expressões das transformações sociais. Disseminou-se a convicção da insuficiência da codificação, e até mesmo da superação de sua função, ante a complexidade da vida contemporânea e o advento de microssistemas jurídicos pluridisciplinares, como o direito do consumidor, o direito ambiental, os direitos da criança, do adolescente e do idoso" [cfr. op. cit., ponto n. ${ }^{\circ} 2$ ("Desenvolvimento do tema no direito brasileiro"].

48 No entanto, Paulo Lôbo salienta que a constitucionalização dos direitos não se confunde com a supressão de matérias tradicionais de direito privado, trasladadas para o âmbito do direito Público, denominada publicização [cfr. op. cit., ponto n I ("aspetos da constitucionalização do direito civil")].

49 Posição defendida por Mário Delgado, op. cit., 240; embora não deixe de ser verdade que a velha dicotomia direito público e direito privado "permanece exercendo função prestante de classificação prática das matérias, à falta de outro critério mais adequado" (Paulo Lôbo, ibid.). 
conceção antropocêntrica do direito privado. Longe nos encontramos do patrimonialismo dos códigos oitocentistas, ainda presente no Código Civil italiano, de 1942. Nestes novos tempos, a dignidade da pessoa humana assume um papel central na construção do ordenamento jurídico. É nessa ótica que é realizada toda a atividade hermenêutica: em conformidade com a Constituição e com a sua abordagem antropocêntrica. Já não há codificação desarticulada dos mandamentos constitucionais ${ }^{50}$. De outro modo, a constitucionalização do direito civil não é episódica, mas surge como uma consequência do Estado Social de Direito ${ }^{5 !}$.

Esse processo de constitucionalização do direito civil não foi isento de críticas por parte das correntes civilísticas mais tradicionais, por se entender que o direito civil e o Direito Constitucional deveriam manter os seus lugares respectivos. De outra banda, foi apontada uma banalização do processo, com a elevação de todas as relações de direito civil ao plano constitucional. Nessa perspectiva, o direito civil passaria a ser uma espécie de apêndice do Direito Constitucional; no entanto, estas vozes críticas afirmam que o direito civil não mudou de natureza e suas matérias somente devem ser tratadas pela Constituição a título excecional e supletivamente ${ }^{52}$.

Independentemente dessas críticas, a constitucionalização do direito civil no Brasil é uma realidade inegável. Tendo em conta a importância da Constituição Federal, diversas questões a que referi, antes de entrar na análise do problema dos microssistemas no direito brasileiro, já vão sendo respondidas. De facto, na ordem jurídica brasileira, a Constituição Federal assume um papel fundamental, pois permite uma articulação entre o Código Civil e os microssistemas. Como resulta das ideias de Natalino Irti, ela constitui

${ }^{50}$ Cfr. Mário Delgado, op. cit., pp. 242-244.

${ }^{51}$ Cfr. Paulo Lôbo, op. cit., ponto n. ${ }^{\circ} 4$ ("O direito civil no estado social"). Para este autor, numa sociedade dominada pela solidariedade social são três as caraterísticas básicas da mudança: a) a relativização dos direitos privados pela sua função social; b) a vinculação ético-social desses direitos; c) o recuo do formalismo do sistema de direito privado clássico do séc. XIX.

52 Sobre estas críticas, cfr. Paulo Lôbo, op. cit., ponto n. ${ }^{\circ} 3$ ("Críticas à constitucionalização do direito civil"). A este propósito, salienta Eugênio Facchini Neto que "a constitucionalização do direito privado não implica a absorção deste último pelo direito constitucional", não se podendo ignorar "a persistência de claras distinções (embora não mais dicotómicas) entre direito público e direito privado. Por isso, "apesar do ocaso das grandes dicotomias, da inexistência de fronteiras rígidas entre o público e o privado, dos fenômenos contrapostos da publicização do direito privado e da privatização do direito público, assim como do movimento em direção à constitucionalização do direito privado, percebe-se que ainda persiste o espaço próprio do direito privado, que não restou absorvido pelo direito constitucional. Trata-se de um direito, porém, que perdeu as suas antigas características de um direito individualista e materialista, para tornar-se mais solidário e ético, passando a ter uma verdadeira função social" (cfr "A constitucionalização do direito privado", Revista do Instituto de Direito Brasileiro, 20 I 2, n. ${ }^{\circ}$ I, pp. 185-238, em particular, pp. 227, 232 e 233). 
o elemento de certeza e de estabilidade introduzido na ordem jurídica; o seu novo centro, que assume uma função anteriormente assegurada pelo Código Civil, enquanto coração do direito privado ${ }^{53}$. Todos os institutos de direito privado são, por isso, influenciados por este novo coração da ordem jurídica que a Constituição Federal representa.

No âmbito da Família, por exemplo, e tal como na ordem jurídica brasileira como um todo, dois princípios fundamentais se destacam: a dignidade da pessoa humana e a solidariedade ${ }^{54}$. A "dignidade da pessoa humana" (artigo I ${ }^{\circ}$, inciso III) surge como princípio fundamental do Estado Democrático de Direito na Constituição Federal. No seu âmbito, a família encontra-se funcionalizada ao desenvolvimento da dignidade das pessoas que a compõem, como instrumento de realização existencial dos seus membros ${ }^{55}$. Este princípio da dignidade da pessoa humana está indissociavelmente ligado ao princípio da solidariedade (artigo $3^{\circ}$, inciso I) ${ }^{56}$. No âmbito familiar, releva, ainda, o princípio da liberdade - nomeadamente, no que se refere à constituição e à extinção de entidade familiar -, bem como da igualdade formal e material - v.g. no que se refere à paridade de direitos entre os cônjuges ou companheiros e entre os filhos. Acrescem ainda o princípio da afetividade, da convivência familiar e do melhor interesse da criança ${ }^{57}$.

53 Ideia enfatizada por Mário Delgado, op. cit., p. 253; bem como por Paulo Lôbo, ibid.

${ }^{54}$ Sobre as fontes constitucionais de Direito da Família, cfr. Paulo Lôbo, op. cit., ponto n 7 ("Constitucionalização dos principais institutos de direito civil").

55 Esta importância da dignidade da pessoa humana no Direito da Família brasileiro encontra-se espelhada na Convenção Sobre os Direitos da Criança, de 1990; bem como no Estatuto da Criança e do Adolescente, do mesmo ano (artigos 4. $.^{\circ}, 15^{\circ}$ e 18 $8^{\circ}$. Pelo contrário, embora o CCB de 2002 não faça qualquer alusão ao princípio da dignidade da pessoa humana, este não pode deixar de determinar a sua interpretação, devido à necessidade de o interpretar em conformidade com a Constituição Federal (cfr. Paulo Lôbo, ibid.).

56 No âmbito familiar, este princípio manifesta-se no dever imposto à sociedade, ao Estado e à família, de proteção ao grupo familiar (artigo 226. ${ }^{\circ} \mathrm{CF}$ ), à criança e ao adolescente (artigo 227. ${ }^{\circ}$ CF) e às pessoas idosas (artigo 230 CF) (cfr. Paulo Lôbo, ibid.).

57 Cfr. Paulo Lôbo, ibid. Segundo este autor, o princípio da afetividade encontra-se implícito na Constituição, embora esta não se confunda com o afeto, visto como facto psicológico ou anímico. A afetividade pode-se presumir, mesmo que falte o afeto e surge como o dever imposto aos pais em relação aos filhos e vice-versa, ainda que "haja desamor ou desafeição" entre eles. Por outro lado, a convivência familiar é a "relação afetiva diuturna e duradoura entretecida pelas pessoas que compõem o grupo familiar, em virtude de laços de parentesco ou não, no ambiente comum". Finalmente, o princípio do melhor interesse da criança significa que "a criança (...) deve ter os seus interesses tratados com prioridade, pelo Estado, pela sociedade e pela família, tanto na elaboração quanto na aplicação dos direitos que lhes digam respeito, notadamente nas relações familiares, como pessoa em desenvolvimento e dotada de dignidade". Para todos estes princípios releva particularmente o artigo $227^{\circ} \mathrm{CF}$. 
A Constituição Federal também tem fortes reflexos na propriedade ${ }^{58}$. Aqui se denota com mais intensidade a tensão entre uma conceção individualista e uma conceção solidária. Esta surge espelhada no artigo $5^{\circ}$, inciso $X X I 1$, que garante o direito de propriedade, quando articulado com o inciso XXIII, do qual resulta a função social da propriedade. Verifica-se, assim, a presença da dimensão solidária do Estado Social, nesse âmbito, como não poderia deixar de ser. Nesse campo, é de salientar que o direito de propriedade deve ser compatível com a preservação do meio ambiente (artigo $225^{\circ}$ da Constituição Federal) ${ }^{59}$. $\bigcirc$ direito de propriedade atual não abrange somente o tradicional domínio sobre coisas corpóreas, envolve a própria atividade económica, nomeadamente, o controlo empresarial, os ativos mobiliários, a propriedade de marcas, patentes, biotecnologias e outras propriedades intelectuais. Várias dimensões do direito de propriedade que se encontram sujeitas à sua função social, conforme resulta da Constituição Federal.

Finalmente, no que se refere ao contrato, a Constituição Federal também tem uma importante palavra ${ }^{60}$. $\bigcirc$ contrato surge como a forma de realização da ordem económica ${ }^{61}$. Resulta dos princípios gerais da atividade económica (artigo $170^{\circ}$ e ss. Da Constituição Federal), que o contrato já não é visto como um acordo celebrado entre indivíduos formalmente iguais e autónomos, como ocorria no paradigma do liberalismo. Embora a regra pacta sunt servanda continue a ter relevância, no âmbito da autonomia privada, os interesses individuais são condicionados, atendendo-se à desigualdade material das partes. Nesse âmbito, é de destacar o já referido Código de Defesa do Consumidor, cuja abrangência é bastante vasta, visto que tem por objeto todas as relações havidas entre destinatários finais dos produtos e serviços presentes no mercado de consumidos, por aqueles que a lei considera fornecedores, ou seja, que desenvolvem atividade permanente e organizada de produção e distribuição dos bens em causa. Também é de destacar a importância do fenómeno das cláusulas contratuais gerais, que implica uma proteção acrescida da parte contratual mais fraca.

58 Sobre as fontes constitucionais da propriedade, cfr. Paulo Lôbo, op. cit., ponto n. 7 ("Constitucionalização dos principais institutos de direito civil").

59 Nas palavras de Paulo Lôbo "O meio-ambiente é bem de uso comum do povo e prevalece sobre qualquer direito individual de propriedade, não podendo ser afastado até mesmo quando ecologicamente sustentável. É oponível a todos e exigível por todos. A preservação de espaços territoriais protegidos veda qualquer utilização, inclusive para fins de reforma agrária, salvo mediante lei" (ibid.).

60 Sobre as fontes constitucionais do contrato, cfr. Paulo Lôbo, op. cit., ponto n 7 ("Constitucionalização dos principais institutos de direito civil").

${ }_{61}$ Segundo Paulo Lôbo "a atividade econômica é um complexo de atos contratuais direcionados a fins de produção e distribuição dos bens e serviços que atendem às necessidades humanas e sociais" (ibid.). 
Em suma, "O conteúdo conceptual, a natureza, as finalidades dos institutos básicos do direito civil, nomeadamente a família, a propriedade e o contrato, não são mais os mesmos que vieram do individualismo jurídico e da ideologia liberal oitocentista, cujos traços marcantes persistem na legislação civil. Sai de cena o indivíduo proprietário para revelar, em todas as suas vicissitudes, a pessoa humana. Despontam a afetividade, como valor essencial da família; a função social, como conteúdo, e não apenas como limite, da propriedade, nas dimensões variadas; os princípios sociais e a tutela do contratante vulnerável, no contrato"62.

\section{A “TEORIA” DO DIÁLOGO DAS FONTES E SUA RELEVÂNCIA NO DIREI- TO BRASILEIRO}

Qual guia fiel de um jurista português aventurando-se nos meandros do direito brasileiro, Mário Delgado não deixa de apontar a próxima pista no caminho que venho trilhando para compreender o problema dos microssistemas jurídicos neste ordenamento jurídico: o diálogo das fontes ${ }^{63}$ ! De facto, recordem-se as questões colocadas logo antes do início da análise do problema dos microssistemas jurídicos no direito brasileiro:

a) Qual a forma de articulação entre os microssistemas e o Código Civil brasileiro?

b) Qual a importância do Código Civil no direito brasileiro?

c) Qual o papel da Constituição Federal no direito privado brasileiro?

d) Que orientações devem os julgadores brasileiros seguir para lidar com a complexidade do direito brasileiro?

Já verificamos que a Constituição Federal assume, hoje, um papel central de unificação da ordem jurídica brasileira, permitindo uma articulação entre os microssistemas e o Código Civil brasileiro, por meio dos seus princípios e normas, que determinam a análise de todas as fontes do direito, constituindo a "lente" à luz da qual essas mesmas fontes são interpretadas. Ficando, ainda, por determinar a relevância do Código Civil brasileiro, vou agora debruçar-me sobre o problema da articulação das diversas fontes entre si, neste ordenamento jurídico "híper-complexo" que é o

62 Como tão bem sintetiza Paulo Lôbo, op. cit., ponto nº 8 ("A imprescindibilidade da constitucionalização do direito civil").

63 "Em suma, o que importa saber é apenas se a Lei Geral, no caso o Código Civil, e as Leis Especiais, guardam uma relação de coerência entre si, de modo a concluirmos que estão inseridas no mesmo sistema normativo. Ou seja, devemos examinar se existem antinomias e se tais antinomias seriam elimináveis, sem afastar-se a aplicação de quaisquer das normas. Para tanto é indispensável o «diálogo das fontes» preconizado por Erik Jayme e Cláudia Lima Marques" (Mário Delgado, op. cit., p. 252). 
direito brasileiro, para responder à última das questões colocadas: Como poderá o julgador brasileiro "navegar" nas águas revoltas deste ordenamento jurídico?

De acordo com Cláudia Lima Marques ${ }^{64}$, o diálogo das fontes, preconizado por Erik Jayme, permite superar os critérios clássicos de solução de conflitos de leis no tempo. Esses critérios pressupõem a retirada de uma das leis - seja a anterior, a geral ou a de hierarquia inferior -, de acordo com os critérios da anterioridade, especialidade e hierarquia. Por meio do diálogo das fontes, evita-se que qualquer uma das leis em conflito seja sacrificada, resolvendo-se eventuais antinomias aparentes. A autora analisou a questão, em particular, no que se refere a uma articulação entre o Código de Defesa do Consumidor e o Código Civil brasileiro, de 2002, para concluir que o aquele não foi revogado por este ${ }^{65}$.

"Aceite-se ou não a pós-modernidade, a verdade é que, na sociedade complexa atual, com a descodificação, a tópica e a micro-recodificação (como a do CDC) trazendo uma forte pluralidade de leis ou fontes, a doutrina atualizada está à procura de uma harmonia ou coordenação entre estas diversas normas do ordenamento jurídico (concebido como sistema)"66. O diálogo das fontes pretende garantir esta harmonia, sugerindo novos critérios para uma coordenação das normas em conflito no sistema. Passa-se de uma lógica de "monólogo", em que somente uma das normas em conflito permanece no sistema (revogação), para um "diálogo" entre as normas conflituantes, para que nenhuma seja sacrificada. Não se trata, por isso, propriamente, de uma teoria, mas de um método para a articulação de fontes legislativas. Nessa nova perspectiva existem três "diálogos" possíveis ${ }^{67}$.

Em primeiro lugar, o diálogo sistemático de coerência, em que, na aplicação simultânea de duas leis, uma destas pode servir de base conceptual para outra, particularmente, se uma delas é a lei central do sistema (geral) e outra um microssistema específico que não se encontra materialmente completo, sendo apenas subjetivamente completo ao visar tutelar um grupo da sociedade. Como exemplo, tenham-se presentes os conceitos de pessoa jurídica, nulidade, prescrição etc., que não vêm definidos no microssistema de defesa do consumidor - ao contrário do que ocorre com outros conceitos como fornecedor, serviço e produto - e resultam do Código Civil, sendo que a entrada em vigor do Código Civil brasileiro, de 2002 implicou uma atualização destes conceitos. De outra forma, à compra e venda de consumo aplicam-se as regras básicas do Código Civil brasileiro, com os princípios do Código de Defesa do Consumidor; tudo num diálogo de coerência).

${ }^{64}$ Cláudia Lima Marques, op. cit., p. 16.

${ }^{65}$ Cláudia Lima Marques, op. cit., p. 35.

66 Nas palavras de Cláudia Lima Marques, op. cit., p. 43.

67 Sobre estes diálogos, cfr. Cláudia Lima Marques, op. cit., pp. 44-46. 
Em segundo lugar, surge o diálogo sistemático de complementaridade e subsidiariedade. Este traduz-se na possibilidade de uma lei incidir de maneira complementar (diálogo de complementaridade - incide de forma direta) ou subsidiária (diálogo de subsidiariedade - incide de forma indireta) na aplicação de outra, num sentido contrário ao da revogação ou da abrogação clássicas, em que uma lei era superada e retirada do sistema por outra. Deste diálogo resulta a conclusão sobre a não revogação do Código de Defesa do Consumidor, de 1990, pelo Código Civil brasileiro, de 2002, nomeadamente, pelo facto de este Código não dispor sobre relações de consumo.

O diálogo de subsidiariedade resulta claramente da possibilidade de aplicação das normas do Código Civil brasileiro às relações de consumo (artigo $7^{\circ}$, do Código de Defesa do Consumidor ${ }^{68}$ ). Assim, se a solução do Código Civil brasileiro se revelar mais benéfica ao consumidor, pode ser topicamente afastada a norma originalmente prevista no Código de Defesa do Consumidor, mediante aplicação daquela prevista no sistema geral. Foi o que ocorreu, por exemplo, em matéria de prescrição, em caso em que o Superior Tribunal de Justiça afastou o prazo de prescrição de cinco anos, previsto no artigo $27^{\circ}$ do Código de Defesa do Consumidor, para fazer incidir a regra do Código Civil brasileiro vigente à data do nascimento da pretensão (19|6), prevendo o prazo prescricional de vinte anos ${ }^{69}{ }^{70}$. No que se refere ao diálogo de complementaridade, tenha-se em conta, por exemplo, que, aos contratos que são de consumo e de adesão ao mesmo tempo, no que diz respeito a cláusulas abusivas, poderá ser aplicado o artigo $51^{\circ}$ do Código de Defesa do Consumidor e o artigo $424^{\circ}$ do Código Civil brasileiro, ambos para proteção dos consumidores.

${ }^{68}$ Artigo $7^{\circ} \mathrm{CDC}$ : "Os direitos previstos neste código não excluem outros decorrentes de tratados ou convenções internacionais de que o Brasil seja signatário, da legislação interna ordinária, de regulamentos expedidos pelas autoridades administrativas competentes, bem como dos que derivem dos princípios gerais do direito, analogia, costumes e equidade".

69 Artigo $27^{\circ} \mathrm{CDC}$ : "Prescreve em cinco anos a pretensão à reparação pelos danos causados por fato do produto ou do serviço prevista na seção II deste Capítulo, iniciando-se a contagem do prazo a partir do conhecimento do dano e de sua autoria".

70 BRASIL. Superior Tribunal de Justiça. Resp n 782.433/MG. Relatora: Ministra Fátima Nancy Andrighi. Nesta decisão entendeu-se que: "O mandamento constitucional de proteção do consumidor deve ser cumprido por todo o sistema jurídico, em diálogo de fontes, e não somente por intermédio do CDC. Assim, e nos termos do art. $7^{\circ} \mathrm{CDC}$, sempre que uma lei garantir algum direito para o consumidor, ela poderá se somar ao microssistema do CDC, incorporando-se na tutela especial e tendo a mesma preferência no trato da relação de consumo. Diante disso conclui-se pela inaplicabilidade do prazo prescricional do art. $27^{\circ}$ do CDC à hipótese dos autos, devendo incidir a prescrição vintenária do art. $177^{\circ} \mathrm{CC} / 16$, por ser mais favorável ao consumidor (...)". Disponível em: https://stj.jusbrasil.com.br. 
Em último lugar, temos o diálogo de coordenação e adaptação sistemática, ou seja, o diálogo das influências recíprocas sistemáticas. Este pressupõe que o Código Civil brasileiro e as suas normas funcionem como base conceptual para interpretação e aplicação do Código de Defesa do Consumidor, e também que a lei geral (CCB) e a lei especial (CDC) se influenciam mutuamente. Este diálogo implica que a forma como a jurisprudência define princípios ou institutos comuns dos dois sistemas normativos (CDC e CCB) pode ser aplicada em ambos, sem prejuízo da autoridade da lei. Assim, a jurisprudência que é produzida a partir das normas de proteção do consumidor, serve, igualmente, à interpretação e aplicação das normas civis (transposição).

Esta ideia de diálogo das fontes ganhou intenso relevo no julgamento na ação direta de inconstitucionalidade $n^{\circ} 2.591$, em 2006, que considerou, conforme a Constituição, a aplicação do Código de Defesa do Consumidor às atividades bancárias, não obstante existisse lei complementar regulamentadora de tais relações ${ }^{7 !}$. A nova lógica de diálogo entre as fontes confere aos magistrados um método para lidar com a complexidade da ordem jurídica brasileira. Doutro modo, permite responder à questão de saber qual a relevância do Código Civil brasileiro, de 2002. Este passa a ser o centro da ordem jurídica privada, conectando os diversos microssistemas, mas à luz da tábua axiológica da Constituição. Não se trata de ideias novas, tendo em conta as pistas deixadas por Natalino Irti, a que diz oportunamente referência ${ }^{72}$.

\section{SÍNTESE CONCLUSIVA NO QUE SE REFERE AO DIREITO BRASILEIRO}

Olhando para os códigos e para a forma como envelhecem, o que potencia o surgimento de microssistemas (leis especiais) que vão regulando numerosas matérias, vimos como a ordem jurídica brasileira foi crescendo em complexidade. De enorme importância nesse processo é a constitucionalização do direito civil, visto que a Constituição Federal surge como centro e elemento unificador de toda a ordem jurídica. Para além deste poder agregador da Constituição, o "diálogo das fontes" surge como ferramenta importante para orientar o julgador no que se refere às relações entre os microssistemas e o Código Civil brasileiro; e destes entre si, em particular, na perspectiva da relação entre este Código e o Código de Defesa do Consumidor.

A tese da exclusividade dos microssistemas, com exclusão de uma recodificação, defendida por Natalino Irti, em Itália, foi negada pela própria realidade, o que demonstra a importância da função de coordenação e integração que o Código Civil brasileiro exerce e que o torna indispensável no seio do direito privado. Este "habita" agora num ordenamento jurídico "ofuscado pelo sol da Constituição Federal", em cujo redor orbitam diversos microssistemas jurídicos. É a partir do Código Civil

71 Disponível em: https://stf.jusbrasil.com.br.

72 Cfr. o ponto $n^{\circ} 2$. 
brasileiro que surgirão guias de regulamentação e de interpretação das relações jurídico-privadas, que se referem à propriedade, contratos, responsabilidade civil etc. Estes não podem ser construídos somente sobre os vagos princípios constitucionais, carecendo da solidez da legislação civil. Por isso, não esquecendo que a Constituição Federal se encontra no vértice da pirâmide, mesmo que o Código Civil brasileiro assuma uma função "residual", utilizando a terminologia de Irti - e assumindo que se trata, efetivamente, de uma função meramente residual - não se deve subestimar a importância dessa mesma função ${ }^{73}$.

Em suma, os microssistemas enriquecem a ordem jurídica brasileira, em articulação com a recodificação e com a importância da Constituição Federal, mesmo no âmbito do direito privado, sendo que o diálogo das fontes permite uma concretização dos princípios constitucionais, ao nortear a articulação entre o Código Civil brasileiro e os microssistemas e dos microssistemas entre si. Como veremos de seguida, todo este cenário indicia uma ordem jurídica muito diferente da portuguesa.

\section{O PROBLEMA DOS MICROSSISTEMAS JURÍDICOS NO DIREITO PORTU- GUÊS E A DIFERENTE "ARQUITETURA" DESTE SISTEMA JURÍDICO}

\section{I O papel criador dos magistrados em Portugal e no Brasil e a constitucionali- zação do direito civil português}

Talvez o ponto mais complexo deste meu estudo seja, precisamente, a análise do problema em questão na ordem jurídica portuguesa. Por isso, o seu título apresenta um ponto de interrogação: Será possível analisar o Direito das Relações Privadas dos Microssistemas jurídicos, numa perspectiva luso-brasileira?

Um bom ponto de partida será a afirmação de Menezes Cordeiro ${ }^{74}$ de que, para além de um certo ceticismo e pessimismo subjacente, para a defesa de uma descodificação contribuiu o facto de a tópica e retórica estarem na ordem do dia, bem como a existência de uma "especial reverência perante os esquemas aparentemente soltos do Direito anglo-saxónico" (o itálico é meu). Este último aspecto chama a atenção de um jurista português que procura compreender a temática dos microssistemas jurídicos no Brasil e em Portugal, visto que traz à memória a diferente "arquitetura" dos dois sistemas jurídicos que se pretende interpretar (um mais solto do que o outro!). A esse propósito foi, recentemente, apontada na doutrina brasileira a aproximação que se verificou nessa ordem jurídica ao sistema de common law, em particular, após

\footnotetext{
73 Recorde-se a afirmação do próprio Natalino Irti, de que a construção dos microssistemas deve partir do Código Civil, visto que este continua a ser o mais "rico e refinado arsenal de instrumentos jurídicos" (op. cit., pp. 98-99).

74 António Menezes Cordeiro, Tratado de Direito Civil, I - Introdução, fontes do direito, interpretação da lei, aplicação das leis no tempo, doutrina geral, p. 149. 
a entrada em vigor do Código de Processo Civil, de 2015 (Lei n 13.105, de 16 e março $)^{75}$. Este incorporou, no direito brasileiro, elementos deste sistema, nomeadamente, no que se refere à regra do precedente ${ }^{76}$. Como vimos, no direito brasileiro,

75 Nesse sentido, cfr. Lucas Alves Edmundo Gomes, "ThelnfluencesofCommonLawontheBrazilian New Codeof Civil Procedure", disponível em: https://papers.ssrn.com/sol3/papers. cfm?abstract_id=3204827 (consultado a 10-7-20 19). Não significa isto que o direito brasileiro se esteja a converter num sistema de commonlaw, embora se trate da conclusão a que chegam diversos estudos recentes em matéria de Direito Processual Civil [cfr. Pedro Henrique Reschke, "Porque o Brasil não está caminhando para o commonlaw e por que isso importa", disponível em: http://melloesouza.adv.br/2018/05/03/por-que-o-brasil-nao-esta-caminhando-para-o-common-law-e-por-que-isso-importa/ (consultado a I I-07-20 I9)].

${ }^{76}$ Entre os novos institutos introduzidos no direito brasileiro, temos o amicuscuriae, que foi um instituto criado no direito romano, amplamente utilizado nos sistemas de commonlaw. Este permite que pessoas e entidades que não têm interesse direito no processo possam influenciar a decisão no mesmo para o usar como um precedente no futuro. Este instituto já existia no Código de Processo Civil de 1973, no artigo 483, mas apenas podia ser utilizado numa declaração de inconstitucionalidade, o que ocorre em poucos casos. Atualmente, a relevância do instituto no novo Código é bastante mais ampla. Assim, de acordo com o artigo $138^{\circ} \mathrm{CPC}$ : "O juiz ou o relator, considerando a relevância da matéria, a especificidade do tema objeto da demanda ou a repercussão social da controvérsia, poderá, por decisão irrecorrível, de ofício ou a requerimento das partes ou de quem pretenda manifestar-se, solicitar ou admitir a participação de pessoa natural ou jurídica, órgão ou entidade especializada, com representatividade adequada, no prazo de 15 (quinze) dias de sua intimação" (o itálico é meu).

Em segundo lugar, temos o uso do precedente. Trata-se de um instituto que existe no direito brasileiro desde a Emenda Constitucional n 45/2004, que fortaleceu a jurisprudência maioritária, através da sua súmula e publicação, servindo de orientação para decisões futuras. As súmulas constituem uma espécie de sumários da jurisprudência anterior e podem ter um efeito vinculante. De acordo com o artigo I03. --A da Constituição Federal Brasileira: "O Supremo Tribunal Federal poderá, de ofício ou por provocação, mediante decisão de dois terços dos seus membros, após reiteradas decisões sobre matéria constitucional, aprovar súmula que, a partir de sua publicação na imprensa oficial, terá efeito vinculante em relação aos demais órgãos do Poder Judiciário e à administração pública direta e indireta, nas esferas federal, estadual e municipal, bem como proceder à sua revisão ou cancelamento, na forma estabelecida em lei" (o itálico é meu). Também o artigo 489, § I, V, do novo Código de Processo Civil determina que não se considera fundamentada qualquer decisão se o juiz "se limitar a invocar precedente ou enunciado de súmula, sem identificar seus fundamentos determinantes nem demonstrar que o caso sob julgamento se ajusta àqueles fundamentos" (o itálico é meu). Isto claramente aponta para a relevância do precedente. Finalmente, ainda de acordo com o artigo $489^{\circ}, \S 1$, VI, não se considera fundamentada qualquer decisão se o juiz "deixar de seguir enunciado de súmula, jurisprudência ou precedente invocado pela parte, sem demonstrar a existência de distinção no caso em julgamento ou a superação do entendimento" (o itálico é meu). Isto também aponta no sentido da relevância da regra do precedente.

Em terceiro lugar, o recurso especial constitui outro exemplo de aplicação de um instituto de commonlawno direito brasileiro. Segundo o artigo I05, III, da Constituição Federal 
a integração entre os microssistemas e o macrossistema codificado dá-se pelos seus pontos em comum, representados, sobretudo, pelos princípios constitucionais fundamentais, base da ordem jurídica como um todo. Eles são o elo sistemático entre o Código Civil brasileiro e os Estatutos (microssistemas). Aqui, o papel da magistratura é fundamental. Tendo isso em conta, um ponto importante para apreender o problema em análise na sua totalidade, é ter em conta o papel diferente que a jurisprudência assume no direito brasileiro - caraterizado por um forte ativismo judicial -, quando comparado com o direito português. Este ponto também mostra o caráter mais solto da ordem jurídica brasileira, nomeadamente, em matéria de microssistemas, quando se trata de reunir num só diploma regras de vários ramos de direito.

No direito português, pode-se apontar que "se é verdade que a jurisprudência não é fonte do direito, ela é sempre uma fonte do conhecimento do direito"77. Isso, sem prejuízo de o julgador ter de tomar em consideração todos os casos que mereçam tratamento análogo, com vista a obter uma interpretação e aplicação uniformes do direito (artigo 8\% 3 , do Código de Processo Civil), o que dá origem à jurisprudência constante.

Brasileira: "Compete ao Superior Tribunal de Justiça: III - Julgar, em recurso especial, as causas decididas, em única ou última instância, pelos Tribunais Regionais Federais ou pelos tribunais dos Estados, do Distrito Federal e Territórios, quando a decisão recorrida: c) Der a lei federal interpretação divergente da que Ihe haja atribuído outro tribunal" (o itálico é meu). Ainda sobre o recurso especial diz o artigo 1.029. do CPCB: "O recurso extraordinário e o recurso especial, nos casos previstos na Constituição Federal serão interpostos perante o presidente ou o vice-presidente do tribunal recorrido, em petições distintas que conterão: $\S 1 \circ$ Quando o recurso fundar-se em dissídio jurisprudencial, o recorrente fará a prova da divergência com a certidão, cópia ou citação do repositório de jurisprudência, oficial ou credenciado, inclusive em mídia eletrônica, em que houver sido publicado o acórdão divergente, ou ainda com a reprodução de julgado disponível na rede mundial de computadores, com indicação da respectiva fonte, devendo-se, em qualquer caso, mencionar as circunstâncias que identifiquem ou assemelhem os casos confrontados" (o itálico é meu)

Por último, tenha-se presente o agravo em recurso especial e em recurso extraordinário. Nos termos do artigo $1042 .^{\circ}$ CPC: "Cabe agravo contra decisão do presidente ou do vice-presidente do tribunal recorrido que inadmitir recurso extraordinário ou recurso especial, salvo quando fundada na aplicação de entendimento firmado em regime de repercussão geral ou em julgamento de recursos repetitivos" (o itálico é meu). Conclui-se, por isso, que o direito brasileiro, especialmente após a aprovação do Código de Processo Civil de 20I5, é fortemente influenciado pelo sistema de commonlaw. Isto resulta claro da maior ênfase dada ao amicuscuriae, bem como à aplicação do precedente. A relevância deste último tem vantagens, tais como a celeridade processual, bem como a segurança jurídica, contribuindo para a estabilidade do direito brasileiro.

77 A frase é de Miguel Teixeira de Sousa, Introdução ao Direito, Coimbra, Almedina, 2013, p. 136. Sobre a jurisprudência enquanto fonte do direito no direito português, cfr., exmultis, esta obra, que constitui umas das reflexões mais recentes, bem como mais interessantes, sobre a matéria na nossa ordem jurídica, em particular, pp. |34- 142. 
Com vista a evitar que existam decisões contraditórias sobre a mesma questão fundamental de direito, no âmbito da mesma legislação aplicável, por parte de tribunais superiores, surge a jurisprudência uniformizada ${ }^{78}$. No entanto, esta não assume um valor normativo, ou seja, não é vinculativa para os restantes tribunais, nem mesmo inferiores, não constituindo, por isso, uma fonte de direito. Não the pode ser negado, de qualquer forma, um especial valor persuasivo, sendo sempre possível interpor recurso da decisão que não siga a jurisprudência uniformizada (v.g. artigo 678\%/2/c, do Código de Processo Civil) ${ }^{79}$. Pelo contrário, os assentos, enquanto antecedentes desta forma de uniformização de jurisprudência, eram fontes de direito. Na versão originária do Código de Processo Civil, o artigo $2^{\circ}$ estabelecia que: "Nos casos declarados na lei, podem os tribunais fixar, por meio de assentos, doutrina com força obrigatória geral" (o itálico é meu). Estes eram emitidos quando era necessário solucionar uma contradição de julgados, sobre a mesma questão fundamental de direito e no domínio da mesma legislação, por meio de um acórdão com força obrigatória geral (artigo 763\% / do Código de Processo Civil, de 1967). Na revisão constitucional, de 1982, foi introduzido o então artigo I I5\%, atual artigo I I $2 \%$, que proibe qualquer lei de atribuir a atos de outra natureza (jurisdicional) o poder de, com eficácia externa, interpretar ou integrar atos legislativos. Tendo em conta este preceito, o Tribunal Constitucional declarou inconstitucional o artigo $2^{\circ}$ do Código de Processo Civil na parte em que atribuía aos assentos força obrigatória geral. Por meio do artigo 4\%/2 do Decreto-Lei n 329-A/95, de 12 de dezembro, a opção do nosso legislador foi no sentido da revogação do instituto dos assentos.

No direito português existem algumas situações em que a jurisprudência é fonte do direito, como acontece no que se refere aos acórdãos do Tribunal Constitucional que declaram, com força obrigatória geral, a inconstitucionalidade ou a ilegalidade de normas (artigo 281\% e 3 da Constituição da República Portuguesa) e aos acórdãos dos tribunais administrativos que declaram com força obrigatória geral a ilegalidade de normas administrativas (artigo $76^{\circ}$ do Código de Processo dos Tribunais Administrativos).

Tendo em conta o que foi mencionado, no que se refere ao papel dos julgadores na criação do direito, verificamos que existe uma diferença considerável entre

${ }^{78}$ O recurso ao pleno das secções cíveis do Supremo Tribunal de Justiça, permite a obtenção dessa uniformização no Processo Civil (artigo 732. -A e 732. ${ }^{\circ}$-B CPC). Esta revista ampliada pode assumir um âmbito individual e com função decisória no caso subjudice, sendo interposto pelas partes (artigo 763.\% / CPC), ou ser interposto pelo Ministério Público unicamente no interesse de unificação do direito e sem função decisória no caso subjudice (artigo 766. ${ }^{\circ} \mathrm{CPC}$ ). Esta uniformização de jurisprudência também se pode verificar no Processo Penal (artigo 437. ${ }^{\circ}$ a488..$^{\circ}$ do Código de Processo Penal); bem como no Contencioso Administrativo (artigos 148..$^{\circ}$ e 152..$^{\circ}$ do Código de Processo dos Tribunais Administrativos).

${ }^{79}$ Cfr. Miguel Teixeira de Sousa, op. cit., pp. |40-।41. 
as ordens jurídicas portuguesa e brasileira. A revogação do instituto dos assentos em 1995 demonstra, talvez, que Portugal caminha no sentido inverso daquele que observamos no Brasil, sendo bastante mais conservador no entendimento do princípio da separação dos poderes. Para além do exemplo dos assentos, pode-se apontar o recurso especial existente no direito brasileiro quando a decisão no caso "der a lei federal interpretação divergente da que lhe haja atribuído outro tribunal" (artigo I05, III, da Constituição Federal Brasileira). Pelo contrário, em Portugal o recurso apenas é permitido quando existe divergência entre a decisão e a jurisprudência uniformizada. Acresce que a proposta de introdução da figura do amicus curiae foi rejeitada em Portugal, na reforma do Código de Processo Civil em $2013^{80}$. Pontos específicos que são o espelho de uma enorme diferença prática, no que se refere ao papel criador dos magistrados, no Brasil e em Portugal.

Ainda para ilustrar essa diferença entre os sistemas jurídicos em análise, no que respeita ao poder criador dos magistrados, referia-se à discussão que ocorreu nas diversas revisões da Constituição da República Portuguesa ${ }^{81}$, nomeadamente, no que se refere ao seu artigo $203^{\circ}$ ("Os tribunais são independentes e apenas estão sujeitos à lei"). Trata-se de uma temática que foi estudada numa dissertação de doutoramento, recentemente defendida na Faculdade de Direito da Universidade de Lisboa, e que foi alvo de acesa discussão ${ }^{82}$. A tese referida baseia-se nas seguintes ideias: a) $\bigcirc$ Direito é normatividade radicada na comunidade, e não em cada indivíduo; b) Recondução das fontes do direito e do método jurídico ao Direito Constitucional, invocando o disposto no artigo $203^{\circ}$ da Constituição da República Portuguesa; c) Íntima ligação entre, por um lado, a democracia e a separação de poderes e, por outro lado, o positivismo legalista; d) Desdiabolização do positivismo legalista, ao desassociar positivismo e Direito da Alemanha Nazi, sendo este um exemplo de Direito eminentemente translegalismo-principalista (direito que admite outras fontes do direito que não os textos legais); e) As reservas perante o translegalismo-principalista judicial apostas, designadamente, por Vital Moreira; f) A vinculatividade das normas

80 Cfr. Ricardo Quintas, "AmicusCuriaeno Direito Processual civil português: o enigma da esfinge de Tebas?", Revista Jurídica Luso Brasileira, 2018, 2, pp. I I I5- I I70, em particular, pp. | |44- | | 45. Disponível em: http://www.cidp.pt/revistas/rjlb/20 |8/2/20 |8_02_ | | 5_ | 170. pdf. Consultado a 10-7-2019.

81 De agora em diante designada CRP.

${ }^{82}$ Cfr. João Pedro Charters Marchante, Das lacunas da lei, no direito português. Maxime, do disposto no art. 203. ' da CRP ("Os tribunais apenas estão sujeitos à lei"), Dissertação de doutoramento em ciências jurídico-civis na Faculdade de Direito da Universidade de Lisboa, sob a orientação do Professor Doutor António Menezes Cordeiro, Lisboa, 20 17, policopiado. Refira-se que as ideias defendidas por este autor não correspondem à visão maioritária na doutrina portuguesa, embora, na minha opinião, coloquem interrogações relevantes, que permitem ilustrar melhor a diferença entre as ordens jurídicas portuguesa e brasileira. 
legais sobre interpretação, retomada por Teixeira de Sousa ${ }^{83}$; g) A reabilitação do subjetivismo historicista operada por Menezes Cordeiro ${ }^{84}{ }^{85}$.

De acordo com esta tese, o direito português consagra o positivismo legalista democrático, em que cabe ao legislador, legitimado pela comunidade portuguesa, a ponderação de interesses conflituantes. Essa ponderação dá origem à criação de normas jurídicas positivadas nos textos legais. Pelo contrário, a ponderação de princípios não cabe aos tribunais, como se retira nomeadamente do referido artigo $203^{\circ}$. Como resulta, igualmente, desta tese, o positivismo legalista exegético-subjetivista-historicista foi ponderado e decidido pela comunidade de forma reiterada, desde 1976, no âmbito das diversas revisões constitucionais, Isso se retira da recusa, durante décadas, de um direito para além da lei (por ocasião das diversas revisões constitucionais, nas votações parlamentares, sempre se recusou alterar o artigo $203^{\circ}$, acrescentando-se-lhe a palavra Direito). Nas mesmas votações parlamentares também se recusou a aplicabilidade pelos tribunais da dignidade da pessoa humana. Finalmente, nas mesmas votações, recusou-se a fórmula Estado de Direito, consagrando-se o Estado de Direito Democrático (artigo $2^{\circ}$, da Constituição da República Portuguesa), o que aponta para que o Direito resulte do poder democrático, expresso na lei ${ }^{86 \_87}$.

83 Miguel Teixeira de Sousa, op. cit., p. 337.

${ }^{84} \mathrm{Na}$ discussão relativa ao subjetivismo ou objetivismo na interpretação da lei, o autor entende que tem de haver um misto entre ambos, ficando as duas hipóteses na disponibilidade do intérprete-aplicador, enquanto vertentes da realização do direito. Por outro lado, acrescenta que, embora na teoria oficial da interpretação o elemento mais ponderoso seja o teleológico, muitas vezes, o elemento mais eficaz é o elemento histórico (cfr. Tratado de Direito Civil, I Introdução, fontes do direito, interpretação da lei, aplicação das leis no tempo, doutrina geral, pp. 685 e 717).

${ }^{85}$ Cfr. João Pedro Charters Marchante, p. IV (“Pedido").

${ }^{86}$ Artigo $2^{\circ} \mathrm{CRP}$ : "A República Portuguesa é um Estado de direito democrático, baseado na soberania popular, no pluralismo de expressão e organização política democráticas, no respeito e na garantia de efetivação dos direitos e liberdades fundamentais e na separação e interdependência de poderes, visando a realização da democracia económica, social e cultural e o aprofundamento da democracia participativa" (o itálico é meu).

87 No contexto dos trabalhos da Revisão Constitucional de 1982, vejam-se as palavras de Vital Moreira, a propósito da proposta de consagração da fórmula de que "Os tribunais (...) apenas estão sujeitos à lei e ao Direito" (aditamento da palavra Direito): "Na verdade, não temos dúvidas nenhumas de que no dia em que fosse aprovada uma coisa destas começariam a pulular os acórdãos judiciais a invocar o direito contra a lei e contra a Constituição. (...) Nós, entre o direito da Assembleia da República portuguesa e o direito dos juristas alemães, preferimos o direito da Assembleia da República. E queremos que os juízes portugueses se determinem pelo direito aprovado pela Assembleia da República e pelos órgãos de soberania, e não por aquilo que a mentalidade jurídico-conservadora alemã entende que é o direito. Era perigosíssimo que uma tal norma fosse aprovada em Portugal no actual contexto, com aquilo que ninguém de boa fé pode 
Em suma, verifica-se que o legislador constitucional português é de uma enorme cautela no que se refere ao poder criador dos magistrados, tendo em conta a insegurança jurídica que dele pode resultar. Os tribunais, devem, por isso, apenas obediência à lei, e não ao Direito. Para se negar essa conclusão, é necessário partir do postulado de que não cabe ao legislador constitucional definir quais as fontes de direito. No entanto, o papel da Constituição no sistema jurídico torna legítimo que se questione esta negação. Esta diferença, no que se refere ao poder criador dos magistrados, mostra o apego dos juristas portugueses à lei e ao sistema, ao contrário da ordem jurídica brasileira, em que se verifica um maior peso da jurisprudência e, igualmente, uma maior liberdade no papel criador dos magistrados. Aparentemente, a proximidade da ordem jurídica brasileira aos sistemas de common law também potenciou uma maior abertura à técnica dos microssistemas. Neste campo, o Brasil e Portugal são irmãos bastante diferentes, sendo a abordagem portuguesa mais conservadora.

\subsection{Constitucionalização do direito civil português?}

Para além da diferença mencionada no que se refere ao poder criador dos magistrados, também se verifica que a constitucionalização do direito civil no direito português não tem a mesma força que no direito brasileiro. Trata-se de um fenómeno que não é difícil de compreender, visto que se prende intimamente com o papel que é reconhecido aos magistrados na concretização dos princípios constitucionais, no que se refere à sua projeção no direito civil. Sabendo nós já que este papel dos magistrados diverge em Portugal e no Brasil, é também natural que o fenómeno da constitucionalização do direito civil tenha um alcance diverso nessas ordens jurídicas.

O problema da eficácia dos direitos fundamentais nas relações entre particulares foi, recentemente, objeto de uma monografia de referência na doutrina portuguesa, por parte de Reis Novais ${ }^{88}$. O autor aponta, à cabeça, que, nas diversas ordens jurídicas, o problema não depende tanto do texto da Constituição, quanto da elaboração doutrinária e da prática jurisprudencial. Como exemplo refere o caso do Brasil, em

ignorar que aconteceria se uma tal norma fosse aprovada, com a sua utilização para abusar das leis democraticamente aprovadas. Admito que, ordem jurídica em que as leis não tenham fundamento democrático, possa ser um meio legítimo de luta política invocar o direito contra essas leis não democráticas. Em todo o caso, mesmo nestas circunstâncias, mais do que invocar o merífico direito contra as leis, o melhor é lutar por alterar as leis (...). Numa República democrática, de leis democraticamente fundadas, não tem fundamento jurídico nem filosófico a invocação como figura autónoma ao lado, e, portanto, também contra a lei. A invocação de uma figura de direito que fica para definição na cabeça de cada juiz, de cada jurista, e assim fica ao abrigo de uma definição subjetiva que não dá quaisquer garantias de segurança, de previsibilidade e de garantias, ao fim e ao cabo, aos cidadãos" (cfr. João Pedro Charters Marchante, op. cit., p. I I 5 e ss., em particular, pp. |19-120).

${ }^{88}$ Cfr. Jorge Reis Novais, Direitos Fundamentais nas Relações entre Particulares, Coimbra, Almedina, 2018. 
que doutrinadores convergem no sentido da aplicabilidade direta nas relações entre particulares dos direitos fundamentais, apesar de a Constituição Federal decretar que "ninguém será obrigado a fazer ou deixar de fazer alguma coisa senão em virtude da lei" (artigo 50, II), o que aponta exatamente no sentido contrário. Nesse contexto, a forma de resolver supostos conflitos de direitos fundamentais será proceder a ponderações ad hoc à luz da dignidade da pessoa humana. No entanto, o autor não deixa de salientar que existe alguma incompreensão dos europeus no que se refere à realidade brasileira. Embora Reis Novais partilhe de uma visão crítica no que se refere a algum ativismo judicial no Brasil, salienta que este é motivado pelos défices de realização dos direitos fundamentais por parte do legislador ou do seu atraso sistemático em face das sociedades sociais mais prementes ${ }^{89}$.

Em 1998, ao pronunciar-se sumariamente sobre a questão no direito português, Gomes Canotilho ${ }^{90}$ salientava os perigos da colonização do direito privado pelos direitos fundamentais constitucionalmente previstos, avançando ideias já aqui referidas a propósito do direito brasileiro, nomeadamente no que se refere a uma inevitável banalização constitucional, vendo as regulações civilísticas, legais ou contratuais, o seu conteúdo substancialmente alterado e perdendo a sua irredutível autonomia. Por isso, e em suma, concluía que "se o direito privado deve recolher os princípios básicos dos direitos e garantias fundamentais, também os direitos fundamentais devem reconhecer um espaço de auto-regulação civil, evitando transformar-se em «direito de não-liberdade» do direito privado".

A tese da eficácia imediata dos direitos fundamentais nas relações entre particulares é fortemente criticada por Reis Novais. Essa crítica demonstra cautela perante a constitucionalização do direito civil que contrasta claramente com o entusiasmo que ela suscita no Brasil. No início do seu estudo sobre a questão, deixa bem claro que, na sua visão, se os particulares pudessem invocar diretamente tais direitos nas relações entre si, estes teriam sofrido uma mudança radical na sua natureza: historicamente concebidos para proteger os cidadãos contra o poder absoluto e ilimitado dos governantes, transformar-se-iam em limite da liberdade e encargo sobre os próprios cidadãos. De outra banda, todas as decisões suscitariam problemas de constitucionalidade, aplicando normas da Constituição, sendo recorríveis para o Tribunal Constitucional. Este passaria a ser o tribunal de recurso ordinário das decisões dos tribunais comuns. Em suma, o Direito Constitucional acabaria por absorver integralmente os

${ }^{89}$ Cfr. Jorge Reis Novais, op. cit., pp. 45-46, 204-205 e 3 I 4.

90 José Joaquim Gomes Canotilho, "Civilização doDireito Constitucional ou constitucionalização do Direito Civil? Eficácia dos direitos fundamentais na ordem jurídico-civil no contexto do direito pós-moderno", in Eros Rogerto GrauMillis Santiago Guerra Filho (org,), Direito Constitucional - Estudos em Homenagem a Paulo Benevides, São Paulo, Malheiros Editores, pp. I 08- I I 5, em particular, p. 113. 
outros ramos de direito". Isso se traduziria numa banalização da ideia de direitos fundamentais e da sua força ${ }^{92}$.

A tese da eficácia imediata dos direitos fundamentais também se traduz numa distorção ao princípio da separação de poderes próprio do Estado de Direito, ao estimular a possibilidade de utilização dos direitos fundamentais contra a autonomia dos indivíduos, com graves inconvenientes em matéria de segurança jurídica ${ }^{93}$. $\bigcirc$ juiz poderia sempre invocar o auxílio dos direitos fundamentais em qualquer conflito entre particulares e, visto que estes encontram a sua base na própria Constituição, prevaleceriam sempre sobre quaisquer atos com valor infraconstitucional. Nesses termos, qualquer resultado seria possível. Também, e por isso mesmo, a própria autonomia privada ficaria limitada, atendendo à potencial utilização dos direitos fundamentais como deveres impostos aos particulares. Para Reis Novais, um juiz menos razoável encontraria aqui um fundamento ideal para "escapar" aos limites legalmente impostos ao poder judicial, decidindo conforme lhe aprouvesse. A tese da eficácia imediata dos direitos fundamentais seria, por isso, um campo fértil para "o decisionismo judicial e arbitrariedade"94. A somar a isto, "tendo em conta que a Constituição raramente fornece ao juiz, no domínio dos direitos fundamentais, pautas e critérios determinados e precisos de decisão (...) as possibilidades de aproveitamento disfuncional dessa indeterminação são consideráveis". "Um juiz menos consciente (...) encontra na tese da aplicabilidade imediata o fundamento/pretexto para ignorar as decisões do legislador, designadamente as que se traduziam no seu silêncio intencional"95. Também é de evitar que a interpretação conforme à Constituição se converta numa autêntica correção "do programa normativo do legislador"96.

\footnotetext{
91 Jorge Reis Novais, op. cit., p. 13.
}

92 Jorge Reis Novais, op. cit., pp. 95-96. Por isso, de acordo com este autor, os defensores da tese da eficácia imediata confrontam-se com um dilema: "ou desvitalizam os direitos fundamentais enquanto garantia jurídica fazendo deles uma utilização meramente retórica, ou, em alternativa, tomam a sério a proclamação de aplicabilidade direta dos direitos fundamentais, mas, com isso, tornariam a vida privada impossível à luz do princípio de liberdade que funda as nossas sociedades".

93 Jorge Reis Novais, op. cit., pp. 96, 103, 105 e 126.

94 Jorge Reis Novais, op. cit., pp. 127 e 133.

95 Jorge Reis Novais, op. cit., pp. 183-184. Como refere Reis Novais, as consequências para a autonomia privada seriam desastrosas, visto que, em caso de conflito, as partes nunca poderiam estar seguras das consequências de um contrato livremente celebrado. Por outro lado, ao recusar a eficácia imediata dos direitos fundamentais, procura-se evitar que os direitos fundamentais sejam utilizados como pretexto de uma intervenção judicial que, em nome da defesa desses direitos, se traduza na imposição das visões políticas e particulares do juiz que não têm qualquer fundamento democrático (Jorge Reis Novais, op. cit., p. 195).

96 Jorge Reis Novais, op. cit., p. 202. 
Ainda se pode apontar a referida tese, que acaba por isentar os agressores da liberdade alheia da reserva de lei, mas somente quando sejam particulares. Ou seja, qualquer particular pode invocar diretamente o seu direito fundamental contra o outro particular, cabendo, segundo esta tese, ao juiz, a ponderação de bens entre os dois direitos fundamentais supostamente em conflito. Dessa ponderação resultará a restrição de um ou de outro desses direitos, a qual será realizada sem necessidade de justificação, i.e., sem observância do princípio da proporcionalidade, da igualdade e da reserva de lei ${ }^{97}$.

Para o mesmo autor, o ponto de partida mais correto na análise deste problema é o de que, se uma lei ordinária não regula determinada situação, isso significa que aí se aplica o princípio da liberdade: aquilo que não está legalmente proibido é permitido ${ }^{98}$. Acresce a particularidade da questão na ordem jurídica portuguesa, visto que a Constituição portuguesa é das poucas que proclama a vinculação dos particulares aos preceitos respeitantes a direitos, liberdades e garantias (artigo 18\%/1)

Afastada por este autor é, igualmente, a tese da aplicabilidade mediata dos direitos fundamentais nas relações entre os particulares, por meio de institutos típicos de direito privado, como as cláusulas gerais e os conceitos indeterminados, e pela interpretação da legislação em conformidade com os novos princípios constitucionais ${ }^{100}{ }^{101}$. Isso, atendendo à existência de situações que não se encontram reguladas

97 Jorge Reis Novais, op. cit., p. 178.

98 Jorge Reis Novais, op. cit., pp. 21 e 74.

99 Jorge Reis Novais, op. cit., p. 29. Ainda a este propósito, Reis Novais salienta o absurdo em que a inovação portuguesa se traduz, visto que "sendo a Constituição portuguesa praticamente a única que consagra a aplicação (eventualmente direta) dos direitos fundamentais às relações privadas, a ordem jurídica portuguesa é também das poucas em que os particulares não podem fazer valer junto do Tribunal Constitucional os direitos fundamentais eventualmente agredidos por outros particulares" (op. cit., p. 40).

100 Jorge Reis Novais, op. cit., pp. 35-36). Embora em Portugal, esta tese seja defendida por civilistas, como António Menezes Cordeiro não significa isto que os civilistas defendam necessariamente a tese da eficácia mediata, e que os constitucionalistas propugnem o "imperialismo" constitucional, como resulta claramente da discussão pioneira sobre a questão na doutrina alemã. Para Menezes Cordeiro, as dúvidas colocadas pela eficácia civil dos direitos fundamentais estão relacionadas com os exageros a que se chegou neste domínio (cfr. Tratado de Direito Civil

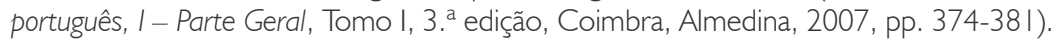

101 Segundo Reis Novais, numa primeira fase, logo após a aprovação da Constituição de 1976 , a doutrina portuguesa dividiu-se entre os defensores da tese da eficácia mediata e aqueles que defendiam a eficácia imediata dos direitos fundamentais, procurando interpretar o artigo I 8. \% / da Constituição à luz dos argumentos resultantes da discussão germânica sobre o assunto. A tal como aconteceu na Alemanha, nessa discussão consolidou-se a ideia de que os direitos fundamentais teriam de ter alguma projeção nas relações entre particulares (op. cit., pp. 47-48). 
na lei e também atendendo a que nem sempre é possível o recurso às cláusulas gerais e aos conceitos indeterminados. Nesse caso, não seria possível afastar uma ameaça a tais direitos fundamentais, no âmbito das relações entre particulares ${ }^{102}$. Acresce a impossibilidade de se realizar uma distinção entre direitos fundamentais só dirigidos ao Estado e outros só dirigidos aos particulares, visto que uma resposta ao problema da eficácia dos direitos fundamentais nas relações entre os particulares só será praticável se for aplicável a todos os direitos fundamentais. De outro modo, ficará sempre ao critério "imprevisível do operador no caso concreto uma discricionariedade de selecção do tipo de direito fundamental susceptível de ser aplicado nas relações entre particulares e da consequente adopção da teoria a aplicar ao caso" 103 .

Pelo contrário, Reis Novais ${ }^{104}$ defende a tese dos deveres de proteção, que vinculam o juiz, enquanto entidade pública. Este deve intervir, para garantir o respeito e acesso individual aos bens constitucionalmente protegidos, também nas relações entre particulares, mesmo na ausência de lei ou de cláusula geral aplicável, visto que nas sociedades democráticas, os conflitos reais e potenciais que ocorrem ou podem ocorrer na sociedade já foram regulados pelo legislador, o ponto em que as diversas teses referidas divergem é o de saber como resolver a situação em que não há lei que a regule, e o preenchimento das cláusulas gerais com recurso à Constituição, ou à interpretação, a esta conforme sejam insuficientes. Reconhece-se uma dimensão objetiva dos direitos fundamentais da qual decorrem especiais deveres de proteção para todos os poderes do Estado, incluindo o poder judicial. Estes deveres permitem ao juiz recorrer à norma constitucional para a resolução de conflitos entre privados, excecionalmente, sempre que o legislador não tenha cumprido os deveres de proteção que lhe cabem em primeiro lugar. Esta atuação do juiz apenas é possível, por isso, se a sua omissão redundasse em insuficiência de proteção ${ }^{105}{ }_{-}^{106}$.

No âmbito da tese dos deveres de proteção, admite-se que o juiz possa intervir para além do que foi decidido pelo legislador, sempre que necessário para garantir o mínimo de proteção devida ao direito fundamental afetado. Pelo contrário, para Reis Novais, "uma visão mais conservadora que exaltasse até ao limite o sentido e o papel

102 Jorge Reis Novais, op. cit., p. 49.

${ }^{103}$ Jorge Reis Novais, op. cit., pp. 55-56.

${ }^{104}$ Jorge Reis Novais, op. cit., p. 67.

105 Jorge Reis Novais, op. cit, pp. 69 e 72-73.

106 Para Reis Novais, não se pode recusar simplesmente qualquer situação de aplicação do Direito Constitucional em nome da autonomia do direito civil. Partindo do pressuposto de que a dignidade da pessoa humana é una e indivisível, não se pode restringir a eficácia dos direitos fundamentais às relações do indivíduo com o Estado. Invocar a autonomia do direito privado seria fazer prevalecer os direitos patrimoniais e o direito de propriedade sobre os direitos de liberdade pessoais (op. cit., pp. 76 e 79). 
da reserva de lei no domínio das restrições aos direitos fundamentais, ataria o juiz de uma forma tão absoluta que não permitiria distinguir, em termos de consequências práticas, a teoria dos deveres de proteção da teoria da eficácia mediata; só o enquadramento teórico seria distinto" ${ }^{107}{ }^{108}$. Esta tese contrasta com a tese da eficácia imediata, porque propugna que a interferência judicial nos contratos ou comportamentos resultantes da autonomia individual só ocorre excecionalmente, como solução de último recurso, e não como situação normal, como consequência da necessidade constante de resolver colisões de direitos fundamentais ${ }^{109}{ }^{110}$. A maior dificuldade com que se depara esta tese, no entanto, é a definição dos limites funcionais do juiz nas situações em que falta a proteção que deveria resultar da atividade legislativa ${ }^{\prime \prime \prime}$.

\section{MICROSSISTEMAS JURÍDICOS NO DIREITO PORTUGUÊS?}

Talvez, após o caminho que foi sendo percorrido, compreenda-se a perplexidade de um jurista português quando é chamado a falar sobre microssistemas jurídicos no Brasil! A existência de microssistemas na ordem jurídica brasileira reflete bem a complexidade de um sistema em que os magistrados assumem um papel essencial. Pelo contrário, em Portugal, o princípio da separação dos poderes é entendido de forma mais conservadora, pelo que o papel criador da magistratura não atinge o mesmo alcance que no Brasil. Dois espíritos muito diversos, que não poderiam deixar de

107 Jorge Reis Novais, op. cit., p. 188.

108 "Há, por isso, normalmente, um espaço de decisão que tem de se reconhecer ao juiz baseado na necessidade de ponderação de factores como a gravidade e intensidade da lesão ou da ameaça que um comportamento privado projecta sobre bens jusfundamentalmente protegidos, a situação particular em que se encontra cada um dos afectados e, em especial, as consequências que a afectação das possibilidades de acesso ao bem jusfundamentalmente protegido projectam sobre as respectivas autonomia e capacidade de autodeterminação" (Jorge Reis Novais, op. cit., p. 189).

109 Jorge Reis Novais, op. cit., p. 75.

110 Apesar de o artigo 18.\% da Constituição consagrar a vinculação das entidades privadas aos direitos fundamentais, para Reis Novais isso significa para os particulares um dever geral de respeito dos direitos, liberdades e garantias que resultam desses preceitos, e não uma consagração da tese da eficácia imediata dos direitos fundamentais (op. cit., p. 252).

III Jorge Reis Novais, op. cit., p. 228. Neste âmbito, Reis Novais seguiu a tese de Canaris, que determina que a intervenção do juiz se deve verificar com base no princípio da proibição de défice. Nesta perspetiva, o controlo constitucional do cumprimento dos deveres de proteção é assumido como um controlo de resultado e como um controlo de mínimos. Segundo Canaris, se se partir do reconhecimento da margem de livre determinação do legislador democrático, poupam-se inevitáveis problemas e dúvidas de separação de poderes que resultam das restantes teses sobre a aplicabilidade dos direitos fundamentais nas relações entre particulares (Jorge Reis Novais, op. cit., p. 255 e ss., em particular, pp. 262 e 266). 
refletir num tema que se prende tão intimamente com a "arquitetura" da ordem jurídica e com a forma de pensamento jurídico que existe no seu seio e que reflete na própria técnica legislativa. Em Portugal, um apego maior ao sistema e à letra da lei; no Brasil, uma maior liberdade jurídica, consentânea com a própria forma de ser do povo brasileiro. No Brasil, a flexibilidade da criação jurisprudencial do direito e da utilização da técnica dos microssistemas, também eles flexíveis; em Portugal, o sistema: o Código Civil, os novos ramos de direito, as leis especiais. Termos diferentes, que refletem espíritos irmãos, mas tão diversos!

Significa isso que, na ordem jurídica portuguesa, o tema dos microssistemas jurídicos não é um "tema", visto que não existem tais microssistemas no direito português? Na minha opinião, a resposta será, seguramente, negativa. No entanto, "arquiteturas" tão distintas em dois sistemas jurídicos implicam um entendimento diferente dos problemas e dos conceitos que se prendem diretamente com tal "arquitetura/ estrutura”. É esse claramente o caso em matéria de microssistemas jurídicos.

Recorde-se que microssistemas jurídicos são um conjunto organizado de normas, princípios e regras tendentes a expressar lógica e unidade às relações jurídicas de determinados grupos, minorias ou temas, abarcando normas de direito material e processual, público e privado. São autênticas ilhas legislativas com lógica própria. E existem microssistemas ou algo semelhante no direito português?

O Código Civil português entrou em vigor no dia $1^{\circ}$ de junho de 1967. É, por isso, normal que existam leis esparsas, tal como ocorreu no Brasil com os microssistemas. Trata-se de um Código com mais de cinquenta anos, pelo que é natural que se encontre desatualizado em algumas áreas, nomeadamente no que se refere ao Direito da Família, em que foram proliferando leis avulsas ${ }^{12}$. Na realidade:

I. A maior parte do regime jurídico da união de facto encontra-se fora do Código Civil, sendo regulada na Lei $n^{\circ}$ 7, de I I de maio de 200 I;

2. A matéria de procriação medicamente assistida é regulada por legislação avulsa desde 2006 (Lei n 32, de 26 de julho de 2006), e o Código Civil somente contém uma disposição sobre a questão (artigo 1.838.\%/3), introduzida em 1977;

3. A matéria do apadrinhamento civil, mais intensa do que a figura da tutela, é regulada pela Lei n 103, de 2009, e totalmente ignorada pelo Código Civil;

112 Sobre este ponto, cfr. o texto muitíssimo esclarecedor de Jorge Duarte Pinheiro, "Atualidade e pertinência do Código Civil em matéria de família e sucessões", in Edição Comemorativa do Cinquentenário do Código Civil, Lisboa, Universidade Católica Editora, 2017, pp. 579-592. Segundo este autor, tarda o terceiro Código Civil português, pelo que, entretanto, deveriam ser aprovados códigos autónomos, um sobre família e crianças e outro sobre efeitos patrimoniais por morte (cfr. "Atualidade e pertinência do Código Civil em matéria de família e sucessões", p. 579). 
4. Os princípios gerais aplicáveis à condição da criança resultam do artigo $4^{\circ}$ do Regime Geral do Processo Tutelar Cível, aprovado pela Lei n 141, de 8 de setembro de 2015 , e do artigo $4^{\circ}$ da Lei de Proteção de Crianças e Jovens em Risco, aprovada pela Lei $n^{\circ} 147$, de $1^{\circ}$ de setembro de 1999;

5. Os aspetos fundamentais da proteção civil da pessoa da criança não são contemplados no Código Civil, com exceção da curta previsão do artigo 1.918 . Tais aspectos resultam da Lei de Proteção de Crianças e Jovens em Perigo (como a concretização das situações de perigo, contemplada no artigo $\left.3^{\circ}\right)^{1 / 3}$.

Para além da questão terminológica, não me parece que se possa dizer que a técnica de legislação por meio de microssistemas seja utilizada no direito português, ou seja, a existência de leis que congregam regras de diversos ramos de direito relativas à mesma matéria. No entanto, existem leis, nomeadamente em matéria de Direito da Família, que preenchem algumas das caraterísticas dos microssistemas, englobando normas processuais e substantivas. Trata-se do caso da Lei de Proteção de Crianças e Jovem em Perigo; porém esta Lei não pode ser comparada com o Estatuto da Criança e do Adolescente do direito brasileiro ${ }^{14}$.

113 Sobre estes aspetos, cfr. Jorge Duarte Pinheiro, "Atualidade e pertinência do Código Civil em matéria de família e sucessões", pp. 584-588.

114 No direito brasileiro, o Estatuto (microssistema) da Criança e do Adolescente (Lei no 8069, de 13 de julho de 1990) regula as seguintes matérias: a) direitos fundamentais (direito à vida e à saúde; direito à liberdade, ao respeito e à dignidade; direito à convivência familiar e comunitária); b) família natural; c) família substituta; d) guarda; e) tutela; f) adoção; g) direito à educação, à cultura, ao esporte e ao lazer; h) direito à profissionalização e à proteção no trabalho; i) prevenção geral e especial (informação, cultura, lazer, esportes e espetáculos; produtos e serviços; autorização para viajar); j) política de atendimento; I) medidas de proteção (gerais e específicas); m) prática de ato infracional (direitos individuais, garantias processuais, medidas sócio-educativas); o) medidas pertinentes aos pais ou responsável; p) conselho tutelar; r) acesso à justiça (justiça da infância e da juventude, juiz, serviços auxiliares, procedimentos, perda e suspensão do poder familiar, destituição da tutela, colocação em família substituta, apuração de ato infracional atribuído a adolescente, apuração de infração administrativa às normas de proteção à criança e ao adolescente, habilitação de pretendentes à adoção, etc.); s) Crimes e infrações administrativas.

Pelo contrário, em Portugal, a Lei de Proteção de Crianças e Jovens em Perigo (Lei n 147/99, de $1^{\circ}$ de setembro) tem uma abrangência de matérias muito menor. Centra-se exclusivamente na situação das crianças em perigo, definindo: as situações de perigo que legitimam a intervenção; os princípios que subjazem a tal intervenção; as entidades que realizam tal intervenção (como as Comissões de Proteção de Crianças e Jovens, cujo funcionamento é aqui regulado); as medidas de promoção dos direitos e de proteção; o procedimento urgente; o processo nas comissões de proteção de crianças e jovens; e o processo judicial de promo- 
Surgem, igualmente, na visão de alguns autores portugueses, novos ramos de direito que englobam matérias de direito público e de direito privado. Assim, há quem defenda a autonomia do Direito das Crianças ${ }^{15}$, bem como do Direito Aéreo ${ }^{16}$. No entanto, não se trata de opiniões pacíficas na nossa doutrina, talvez porque, ao contrário do que ocorre no Brasil, os juristas portugueses, sendo ligados ao sistema, tenham a tendência de separar claramente os ramos de direito em ramos de direito público e ramos de direito privado. É por isso mesmo que Menezes Cordeiro enten-

ção e proteção. De fora ficam matérias que são reguladas no direito brasileiro pelo Estatuto da Criança e do Adolescente tais como: guarda, tutela, adoção, estatuto do menor infrator, infrações administrativas e direitos fundamentais das crianças e dos jovens. Isto mostra-nos a diferença entre o direito brasileiro e o direito português em matéria de microssistemas. Tenha-se presente que, em Portugal, Clara Sottomayor, na sequência das ideias defendidas por António Menezes Cordeiro, entende que seria muito útil a compilação de um Código das Crianças, que contribuiria para facilitar o trabalho dos juristas, perante o estado atual de dispersão das fontes, e facilitaria a autonomização do Direito das Crianças (cfr. "O Direito das Crianças, um novo ramo do direito", in Temas de Direito das Crianças, Coimbra, Almedina, 20 I 4, pp. 21 -64, em particular, p. 49).

115 Visto um ramo do direito como um conjunto de normas jurídicas que regulamentam uma determinada secção ou fatia da realidade social, o Direito das Crianças surge numa área em que se interpenetram vários ramos de direito público e privado. É o caso do Direito da Família, do Direito Internacional Público e do Direito Comunitário, do Direito Constitucional, do Direito Penal e Processual Penal, do Direito do Trabalho, do Direito Fiscal e do Direito da Segurança Social. Para Clara Sottomayor, trata-se de um novo ramo do direito em formação (op. cit., p. 45).

116 Direito Aéreo é constituído pelo conjunto de regras que disciplinam a atividade aeronáutica. Embora seja discutível a autonomia do Direito Aéreo e a sua consequente classificação como ramo do direito, para aqueles que a defendem, este divide-se em direito público e direito privado. Em algumas matérias a autoridade administrativa com atribuições no domínio da aviação integra a relação jurídica e aí exerce competências públicas de autoridade que the estão por lei cometidas. Tudo isto é Direito Público Aéreo. Este reporta-se a: aspetos relativos à navegação aérea, safetyandsecurity, atos de interferência ilícita na aviação, estatuto do comandante, aeroportos (infraestutura aeroportuária), aeronaves (nacionalidade, registo, areonavegabilidade, etc.), facilitação (conjunto de medidas que visam desembaraçar a aeronave, tripulantes, passageiros e a carga aérea) e regras de mercado/concorrência. $\bigcirc$ Direito Privado Aéreo reporta-se às normas que têm por objeto relações jurídicas entre particulares, encontrando-se estes em posição de igualdade jurídica formal (v.g. contrato de transporte aéreo, responsabilidade civil do transportador aéreo, constituição de garantias, ónus ou direitos sobre aeronaves, normas substantivas de arresto preventivo de aeronaves, etc.). Mesmo no Direito Privado Aéreo, a fonte das normas pode ser uma fonte de Direito Internacional Público (v.g. a Convenção para a Unificação de Certas Regras Relativas ao Transporte Aéreo Internacional, Montreal, 28 de maio de 1999) [cfr. Carlos Neves Almeida, "Linhas gerais da evolução do Direito Aéreo", in Dário Moura Vicente (coordenador), Estudos de Direito Aéreo, Coimbra, Coimbra Editora (grupo WoltersKluwer). 20 I2, pp. II-93, em particular, pp. 8-2 I]. 
de que o Direito do Consumo não é um novo ramo do direito, porque este setor jurídico carece de unidade, tendo em conta que engloba regras: sobre a formação dos contratos, publicidade, responsabilidade civil, regras técnicas sobre o tratamento e a apresentação de certos produtos, regras processuais, regras sancionatórias e regras administrativas $^{117}$. No direito português existe a Lei de Defesa do Consumidor (Lei n 24, de 3 I de julho de 1996), mas esta não tem a abrangência de matérias que observamos no Código de Defesa do Consumidor brasileiro (Lei n 8.078, de II de setembro de 1990), o que se torna claro observando as matérias que são tratadas por cada um dos diplomas ${ }^{1 / 8}$.

\section{CONCLUSÃO}

Dois irmãos diferentes; duas ordens jurídicas contrastantes.

Duas formas de pensar o sistema jurídico e de conceber, nele, o papel da Constituição.

117 António Menezes Cordeiro, Tratado de Direito Civil português, I - Parte Geral, Tomo I, p. 209. No entanto, o mesmo ilustre civilista parece aceitar que o Direito do Ambiente constitui uma disciplina autónoma, embora afirme, igualmente, que "o desafio reside em passar de um Direito do ambiente sistemático, isto é, apenas assente numa recolha de normas relativas ao ambiente, para um Direito do ambiente dogmático: um Direito do ambiente ordenado, com princípios e linha de aplicação" (cfr. Tratado de Direito Civil português, I - Parte Geral, tomo I, p. 226).

118 O Código de Defesa do Consumidor (Brasil) com $1 / 9$ artigos regula matérias tão amplas quanto: direitos do consumidor; política nacional de relações de consumo; qualidade de produtos e serviços (ex: proteção à saúde e segurança); prevenção e reparação dos danos (ex: responsabilidade por vício do produto e do serviço); práticas comerciais (ex: publicidade); proteção contratual (ex: cláusulas abusivas, contratos de adesão); sanções administrativas; infrações penais; defesa do consumidor em juízo; sistema nacional de defesa do consumidor; e convenção coletiva de consumo.

Pelo contrário, a Lei de Defesa do Consumidor (Portugal), com 25 artigos apenas, regula os direitos do consumidor (segundo o artigo $3^{\circ}$, estes englobam o direito a: qualidade dos bens e serviços; proteção da saúde e da segurança física; formação e à educação para o consumo; informação para o consumo; proteção dos interesses económicos; prevenção e à reparação dos danos patrimoniais ou não patrimoniais que resultem da ofensa de interesses ou de direito individuais homogéneos, coletivos ou difusos; à proteção jurídica e a uma justiça acessível e pronta; e à participação, por via representativa, na definição legal ou administrativa dos seus direitos e interesses). A mesma lei reporta-se ainda ao caráter injuntivo dos direitos dos consumidores e às instituições de promoção e tutela dos direitos dos consumidores. No entanto, não é esta lei que regula, por exemplo, aspetos relacionados com a publicidade, sanções administrativas, infrações penais e aspetos processuais. Apesar de o microssistema de proteção ao consumidor no Brasil não se esgotar no Código de Defesa do Consumidor, existe uma diferença substancial entre este e a Lei de Defesa do Consumidor portuguesa. 
Dois modos de encarar o princípio da separação de poderes e o papel criador dos magistrados.

Modos diversos, mas complementares, de ser e de legislar!

Aquém Atlântico, a certeza e a segurança do sistema!

Além Atlântico, a flexibilidade e a "equidade" dos microssistemas!

\section{REFERÊNCIAS}

ALMEIDA, Carlos Neves, "Linhas gerais da evolução do Direito Aéreo", in Dário Moura Vicente (coordenador), Estudos de Direito Aéreo, Coimbra, Coimbra Editora (grupo WoltersKluwer). 20 I2, pp. II-93.

AMARAL, Francisco, "Transformação dos sistemas positivos: a descodificação do direito civil brasileiro", disponível em: http://www.anoreg.org.br/index.php?option=com content\&view $=$ article\&id $=398$ :imported_366\&catid $=32 \& \mid$ temid $=|8|$ (consultado a $|5-7-20| 8)$.

CERVO, Fernando António Sacchetim, "Codificação, descodificação e recodificação - do monossistema ao polissistema jurídico", Revista Magister de Direito Civil e Processual Civil, 58, 20I4, pp. 80-86, em particular, p. 83. Disponível em: http:// www.lex.com.br/doutrina_26099622_CODIFICACAO_DESCODIFICACAO_E_ RECODIFICACAO_DO_MONOSSISTEMA_AO_POLISSISTEMA JURIDICOC. aspx (consultado a 4-7-20 I9).

CANOTILHO, José Joaquim Gomes, "Civilização do Direito Constitucional ou constitucionalização do Direito Civil? Eficácia dos direitos fundamentais na ordem jurídico-civil no contexto do direito pós-moderno", in Eros Rogerto Grau/Willis Santiago Guerra Filho (org,), Direito Constitucional - Estudos em Homenagem a Paulo Benevides, São Paulo, Malheiros Editores, pp. 108-I 15.

CORDEIRO, António Menezes, Tratado de Direito Civil português, I - Parte Geral, Tomo I, $3^{\text {a }}$ edição, Coimbra, Almedina, 2007.

CORDEIRO, António Menezes, Tratado de Direito Civil, I - Introdução, fontes do direito, interpretação da lei, aplicação das leis no tempo, doutrina geral, $4^{a}$ edição (reformulada e atualizada), Coimbra, Almedina, 2012.

DELGADO, Mário Luiz, Codificação, descodificação e recodificação no direito civil brasileiro, São Paulo, Editora Saraiva, 20 I I.

GOMES, Lucas Alves Edmundo, "The Influences of Common Law on the Brazilian New Code of Civil Procedure", disponívelem: https://papers.ssrn.com/sol3/papers. cfm?abstract_id=3204827 (consultado a 10-7-20 I9). 
IRTI, Natalino, «L'Etádelladecodificazione»Vent’anni dopo, Milano, Guiffrè, 1998.

LÔBO, Paulo, "Novas perspectivas da constitucionalização do direito civil", disponível em: https://jus.com.br/artigos/2536I/novas-perspectivas-da-constitucionalizacaodo-direito-civil (consultado a 8-7-2019).

MACHADO, João Baptista, Introdução ao Direito e ao Discurso Legitimador, Coimbra, Almedina, 2000.

MARCHANTE, João Pedro Charters, Das lacunas da lei, no direito português. Maxime, do disposto no art. $203^{\circ}$ da CRP ("Os tribunais apenas estão sujeitos à lei"), Dissertação de doutoramento em ciências jurídico-civis na Faculdade de Direito da Universidade de Lisboa, sob a orientação do Professor Doutor António Menezes Cordeiro, Lisboa, 2017, policopiado.

MARQUES, Cláudia Lima, "Superação das antinomias pelo diálogo das fontes: o modelo brasileiro de coexistência entre o Código de Defesa do Consumidor e o Código Civil de 2002", Revista da Escola Superior de Magistratura de Sergipe, n 7 , 2004, pp. 15-54.

MORAIS, Daniel de Bettencourt Rodrigues Silva, Viabilidade de uma unificação jussucessória a nível europeu: unificação meramente conflitual ou unificação material?, Coimbra, Almedina, 2005.

NETO, Eugênio Facchini, "A constitucionalização do direito privado", Revista do Instituto de Direito Brasileiro, 2012, n I, pp. 185-238.

NOVAIS, Jorge Reis, Direitos Fundamentais nas Relações entre Particulares, Coimbra, Almedina, 2018.

PINHEIRO, Jorge Duarte, "Atualidade e pertinência do Código Civil em matéria de família e sucessões", in Edição Comemorativa do Cinquentenário do Código Civil, Lisboa, Universidade Católica Editora, 2017, pp. 579-592.

PINHEIRO, Jorge Duarte, O Direito da Família Contemporâneo, 6ª edição, Lisboa, Associação Académica da Faculdade de Direito de Lisboa, 2018.

QUINTAS, Ricardo "AmicusCuriaeno Direito Processual civil português: o enigma da esfinge de Tebas?", Revista Jurídica Luso Brasileira, 20 I 8, 2, pp. I I I 5- I I 70.

RESCHKE, Pedro Henrique, "Porque o Brasil não está caminhando para o commonlaw e por que isso importa", disponível em: http://melloesouza.adv.br/20 I8/05/03/porque-o-brasil-nao-esta-caminhando-para-o-common-law-e-por-que-isso-importa/ (consultado a ||-7-20|9)]. 
SOTTOMAYOR, Clara, "O Direito das Crianças, um novo ramo do direito", in Temas de Direito das Crianças, Coimbra, Almedina, 20I4, pp. 21 -64.

SOUSA, Miguel Teixeira de, Introdução ao Direito, Coimbra, Almedina, 2013.

TEPEDINO, Gustavo, "O Código civil, os chamados microssistemase a Constituição: premissas para uma reforma legislativa", in Gustavo Tepedino (Org.), Problemas de direito civil-constitucional, Rio Janeiro, Renovar, 2000, pp. I - 16, disponível em: http:// www.tepedino.adv.br/wpp/wp-content/uploads/20 17/07/Codigo_civil_chamados_ microssistemas_constituicao_fls_000 I-00 l 6.pdf (consultado a 4-7-20 I 9).

Recebido em: 19/07/2019

Aprovado em: 28/08/2019 